Est Ag 39 (2004) 79-134

\title{
El aprendizaje de los sentidos
}

\section{1.- LA GUARDA DE LOS SENTIDOS}

Somos"sentidos", inteligencias sentientes, como dijo Zubiri1. Tenemos tales sentidos y no otros, y esto determina nuestra percepción de la realidad. La peculiaridad de cada sentido nos trae un aspecto distinto de ella. Una cosa oída es distinta cuando se la ve o se la gusta o se la palpa o se la huele. Los sentidos son parte constitutiva de nuestra estructura empírica. Tal hecho basta para descalificar la secular tradición que les ha sido adversa.

Para los gnósticos y los neoplatónicos, para los monjes y los seguidores de su espiritualidad, que, más o menos maquillada, ha llegado hasta nuestros mismos días, gozar de los sentidos es enviscarse en la ciénaga de la materia. El placer sensual es el escalón que precipita en la lujuria, en el sexo, degradación ínfima del hombre. Por él, el hombre se hunde en la lóbrega multiplicidad de las apariencias alejándose del Uno. Las realidades sensibles son motivo constante de tropiezo; hay que huir de ellas. El mundo en que vivimos es vano y efímero, sombra, vislumbre, reflejo del mundo en que no vivimos. Tiene "más de apariencia que de sustancia" y su ser es "casi de burlas"2. Su destino es ser usado, no gozado; usado en Dios, por Dios y para Dios. Las realidades materiales se deben ver como meros símbolos de realidades espirituales, como despertadores del más allá, como "veladores" que vocean al alma que no se detenga en ellas y siga hacia el que las hizo3.

Usar y no gozar de los bienes de este mundo es un principio que aparece con frecuencia en los estoicos, y de ellos pasó a los cristianos. "El alma grande no considera suya ninguna de estas cosas que la rodean, sino que usa

1. Cf. Inteligencia sentiente, Alianza Editorial / Sociedad de Estudios y Publicaciones, Madrid 1980.

2. Fray Luis de LEÓn, De los nombres de Cristo, l. 3, Hijo de Dios, edición de Cristóbal Cuevas, Ediciones Cátedra, Madrid 1977, 517.

3. San Alonso DE OROzCO, Monte de contemplación, c. 10, en Obras del ven. siervo de Dios fr. Alonso de Orozco, Imprenta del ven. siervo de Dios fr. Alonso de Orozco, Madrid 1736, II, 150. 
de ellas como prestadas a guisa de viajero presuroso"4. "Gozar de una cosa es adherirse a ella por amor a ella misma; usarla es servirse de ella para obtener lo que amas si es que debe ser amado [...]. Si queremos retornar a la patria, adonde podamos ser felices, tenemos que usar de este mundo, no gozar de él"5. "Usa del mundo, no te dejes enredar por él [...]. Eres caminante, esta vida es una posada. Utiliza el dinero como utiliza el viajero la mesa, el vaso, la olla y la cama que hay en ella. Como quien está de paso y no va a permanecer" 6 . Este usar de las criaturas tanto cuanto ayuden al hombre para el fin que fue creado y privarse de ellas tanto cuanto se lo impidan es el pincipio y fundamento de los Ejercicios espirituales de san Igancio de Loyola.

En el libro X de las Confesiones, san Agustín, después de bucear en la memoria, hace un detenido examen de conciencia. Constata que su carne aún se le rebela durante el sueño, movida por las imágenes que el tacto ha dejado en la memoria, y que todavía consiente y se deleita "en una acción semejante a la real"7. Contra el placer de la comida lucha diariamente con ayunos para no traspasar "los límites de la necesidad"8. De los perfumes no se preocupa. Ni los busca ni los rechaza, "dispuesto siempre a no tenerlos"9, aunque nunca se sabe lo que está oculto en el corazón del hombre. Más peligrosos le son los deleites del oído, "en los que se vio enredado y subyugado" de joven ${ }^{10}$ (se refiere a la música). Hasta de la música con que se cantan en la Iglesia los salmos de David siente escrúpulos, temeroso de quedar prendido en ella y no subir hasta Aquel del que hablan las palabras. Por eso, recomienda, siguiendo a san Atanasio, que se canten los salmos "con voz clara y adecuada modulación [...], con tan moderada inflexión de voz, que más que a una canción se aproximen a una recitación"11. Siglos más tarde, santa Teresa mandará a sus monjas que, cuando haya que cantar los salmos, los canten "recto tono", sin notas, y no "por punto", lo que Jean Baruzi ha llamado "un extraño y poderoso susurro". El mismo canto gregoriano aten-

4. SÉnECA, Cartas a Lucilio 120, en Lucio Anneo SÉnECA, Obras completas, edición de Lorenzo Riber, Aguilar 19665 764.

5. San Agustín, La doctrina cristiana 1, 4, 4.

6. ÍD., Tratados sobre el Evangelio de san Juan 40,10. En el Sermón 14, 6 y en otros textos repite esta misma idea.

7. Confesiones 10, 30, 41. Examen de conciencia hace también en Soliloquios 1, 8-14, 16-26 y en el Sermón 229 (Denis 6), 3.

8. Ib. $10,31,43.47$.

9. Ib. $10,32,48$.

10. Ib. $10,33,49$.

11. Ib. 10, 33, 50 . 
ta "contra el sentido de retiro y silencio", ya que exige una atención que no deja pensar completamente en Dios ${ }^{12}$.

El diálogo De musica libri VI, comenzado en Milán mientras se preparaba para el bautismo, fue redactado definitivamente en África hacia el año 389. En realidad, es un tratado de métrica latina, de los números (ritmos) poéticos. Al canto y a la danza, que con la palabra eran las tres artes del movimiento, se refiere solo de pasada. Pensaba dedicarles también su tiempo, pero nunca llevó a cabo su proyecto. El libro VI, que para nosotros no tiene razón de ser, es para él el fundamental. "Fruto de los otros"13, dice, coronación de todo el libro. Frente a los otros manuales que se limitaban a tratar estrictamente de métrica, como debe ser, él se eleva de los ritmos corporales y espirituales a los ritmos inmutables de la razón, que tienen su origen en Dios, fuente de toda armonía. De lo sensible a lo trascendente, del saber técnico a Dios de acuerdo con las ascensiones de Plotino. Si no es así, dice, la prosodia y cualquier otra rama del saber humano son puras bagatelas indignas de ocupar la mente de un hombre ${ }^{14}$. ¡Felices aquellos que, ateniéndose sólo a la Sagrada Escritura, honran a Dios sin necesidad de estos conocimientos! Si él se ha detenido en ellos, es siguiendo el ejemplo de "hijos piadosos de la Iglesia católica que, educados en su juventud en el arte de hablar y discutir, se sirvieron de estas artes para refutar a los herejes, que embaucan a los débiles con falsas promesas de razón y ciencia"15. En las Retractationes $(1,11,1-4)$ insiste en este tema y en él insiste en la Carta 101, 3-4. Pero por mucho que insista, no hay modo de subir a Dios desde la métrica si, previamente, no se tiene su mentalidad neoplatónica y su doctrina de la iluminación por el Verbo. Es decir, si no se da por supuesto lo que hay que demostrar. Quienes nos dedicamos a estos asuntos lo sabemos bien. Y no por quedarse en la métrica se es frívolo o se busca "el estruendo de los aplausos", como afirma él ${ }^{16}$. También la poesía tiene sus placeres y es muy saludable tomarles el gusto, complacerse en el puro placer estético, enviscarse deleitosamente en él.

¿Quién enumerará los peligros de la vista? Las formas de los cuerpos, tan "variadas y bellas"17, y el encanto de los colores no dan reposo a nues-

12. San Juan de la Cruz y el problema de la experiencia mística, Junta de Castilla y León, Valladolid 1991, 232. Cf. Santa TERESA DE JESús, Constituciones I, 4, en Obras completas, BAC, Madrid 19796, 635; ÍD., Visita de descalzas, 30, ib., 657.

13. La música $6,1,1$.

14. Para las relaciones de san Agustín con la cultura, cf. Pedro LANGA, San Agustín y la cultura, Editorial Revista Agustiniana, Madrid 1998.

15. La música 6, 17, 59 .

16. Ib. $6,1,1$.

17. Confesiones 10, 34, 51. 
tros ojos. La misma luz, que tanto nos alegra, "se insinúa blandamente"18, aunque no le prestemos atención, y nos impide ver la luz verdadera, la que alumbra nuestro interior. Llevados de su apego a lo sensible, los hombres han multiplicado los señuelos que los apartan de Dios: vestidos, calzados, vasos, pinturas y todo un sinnúmero de invenciones no necesarias. Aman la belleza perecedera y se olvidan de la Hermosura increada sin la que ellos, que crean estas bellas cosas efímeras, no existirían. Ninguna de estas cosas sensibles merece ser amada, ni siquiera contemplada por sí misma, sino sólo como apoyo para subir al que las creó. Y, sin embargo, esto es lo que los hombres aman. "Viajan los hombres por admirar las alturas de los montes y las grandes olas del mar y las anchurosas corrientes de los ríos y la inmensidad del océano y los movimientos de los astros y se olvidan de sí mismos, ni se admiran de que tienen en su memoria las imágenes de todas estas cosas recibidas por los sentidos" 19 . No es extraño que en los escritos de Agustín no encontremos paisajes. Ni una humilde violeta florece en ellos. En cambio, ¡cuántos rostros, cuántas presencias humanas! Pero de estas mismas presencias nunca hace un retrato externo; sí nos dice, en cambio, y ¡con qué intensidad a veces!, sus cualidades interiores.

Añádanse a todos estos placeres de la concupiscencia de la carne, placeres de los sentidos, los de la curiosidad, que se disfraza con el nombre de conocimiento. En las Sagradas Letras se la llama concupiscencia de los ojos. Esta es la que lleva a las gentes a contemplar, aunque las horrorice, un cadáver dstrozado; la que llena los teatros y anfiteatros. En las Confesiones, cuenta el caso de su amigo Alipio. No era amigo de los espectáculos que se daban en los anfiteatros, pero un día, arrastrado por los amigos, fue a un combate de gladiadores. Hizo propósito de cerrar los ojos para no ver la crueldad y así lo cumplió; pero, de pronto, la multitud lanzó un rugido. Vencido por la curiosidad, abrió los ojos y, al ver la sangre, se abrevó en ella y con ella "bebió la crueldad y se embriagó del placer sangriento". Hecho uno más de la turba, enardecido, comenzó a vocear locamente. Su alma fue derrocada de la alta ciudadela, y se hizo un forofo empedernido durante mucho tiempo hasta que la misericordia del Señor vino a sacarle de su estado de perversión ${ }^{20}$. La curiosidad es la que lleva a practicar las artes mágicas y demás supercherías, e incluso a tentar a Dios pidiéndole signos por el solo gusto de verlos. Curiosidad es que "los hombres pierdan inútilmente el tiempo escudriñando la naturaleza, cuyo conocimiento nos

18. $I b ., i b$.

19. $I b .10,8,15$.

20. Ib. $6,8,13$. 
sobrepasa"21. Las ciencias de la naturaleza no tienen cabida en el sistema agustiniano. Su objeto está fuera de nuestro alcance y, aunque no lo estuviera, sería darles un tiempo que sólo a Dios se le debe dar. La naturaleza se contempla religiosamente viendo en ella al Creador, no se indaga en ella.

"De esta selva inmensa, llena de asechanzas y peligros"22, él ha salido ya, loado sea el Señor. Ya no va al anfiteatro a contemplar un perro corriendo tras una liebre, pero todavía este espectáculo le atrae la atención, apartándole de más altos pensamientos, si, casualmente, yendo de viaje, se lo encuentra en el campo ${ }^{23}$. Aunque al punto siente que Dios le amonesta a levantar su corazón hacia Él y a "despreciarlo todo y pasar adelante"24. Lo mismo le ocurre cuando, en casa, se queda embobado viendo cómo caza moscas el estelión, y cómo las envuelve en sus redes la araña. Aún cae en estos pequeños espectáculos, tan peligrosos como los otros. Por suerte, se levanta pronto y alaba a Dios, Creador y Ordenador de las cosas grandes y de las pequeñas. También le sucede, a veces, que todas estas vanidades acumuladas en su corazón vuelven impetuosamente a hacérsele presentes en la memoria e "interrumpen y perturban sus oraciones"25.

Todos estos espectáculos de caza y crueldad le sirven para hacer un minucioso análisis del corazón humano y de la presencia del cuerpo en nuestro deseos, aun en los involuntarios. La carne es frágil y se deja llevar fácilmente de sus instintos crueles. ¿Qué es la historia sino una carrera interminable de luchas y muertes, de vencedores y vencidos? Las realidades sensibles nos asedian sin darnos tregua. Hay que estar vigilantes, en atalaya, para ver, ya de lejos, las flechas del enemigo y desviarlas a tiempo ${ }^{26}$. Hay que emplear los esfuerzos en cosas más serias que estas sensibles; entrar en el interior, en los dentros de la memoria, y contemplar, anodado, el espectáculo insondable de uno mismo; purificar el ojo interior, meditar día y noche las Escrituras para que el sol de la Verdad nos ilumine. "No os amoldéis al mundo este (Rom 12, 2); absteneos de él. Evitándolo, vive el alma, que, deseándolo, muere. Contened la fiereza cruel de la soberbia, la indolente voluptuosidad de la lujuria y el engañoso nombre de la ciencia [...], porque el orgullo altanero y el placer de la libido y el veneno de la curiosi-

21. Ib. $10,35,55$.

22. $I b .10,35,56$.

23, Cf. Michel Despland, L'évêque, le lièvre et le chien, en Études Théologiques et Religieuses 77 (2002) 401-414.

24. Confesiones $10,35,57$.

25. Ib., Ib.

26. Cf. Carta 243, 1. 
dad son movimientos de un alma muerta [...], que muere al apartarse de la fuente de la vida y ser recibida, así, por este mundo que pasa, amoldándose a él" 27 .

Representante del más rígido espíritu monástico fue san Anselmo, quien consideraba que "la realidad es tanto más perjudicial cuantos más sentidos satisface. Por eso tenía por peligroso sentarse en un jardín con rosas, que halagan la vista y el olfato, y canciones que encantan el oído"28. Con semejante doctrina, la existencia humana no vale nada. Carece por sí misma de interés y vale en tanto en cuanto esté expresamente orientada hacia Dios. La historia, de suyo, no tiene consistencia, ni hay valores ni derechos humanos.

Sabida es la animadversión de san Bernardo de Claraval a las artes plásticas, su furia iconoclasta, que le llevó a destrozar imágenes de pórticos y capiteles. Tales figuraciones no tenían cabida en el Císter. En su Apología al abad Guillermo escribe: "¿Qué decir de la asombrosa colección de imágenes, a cuál más curiosa y grotesca, esculpidas en los capiteles de los claustros? Monos inmundos, fieros leones, horribles centauros, soldados combatiendo, cazadores con bocinas, quimeras de varias especies [...]. A los monjes les agrada más leer en los mármoles que en los códices y pasarse todo el día admirando tanto pormenor sin meditar en la ley de Dios"29. El monje tiene que vivir dentro de sí mismo, no fuera, en oración continua, atento a las posibles visitas del Esposo, y las obras de arte dificultan la contemplación de esas realidades invisibles. "Para ganar a Cristo, sigue diciendo en la Apología, tenemos por basura todo lo que atrae por su belleza, lo que agrada por su sonoridad, lo que embriaga con su perfume, lo que sabe bien por su dulzura, lo que deleita al tacto, en suma, cuanto satisface al cuerpo"30. Además de falta de sensibilidad para una de las más altas expresiones del arte cristiano, el románico, hay aquí, como en toda la Apología, una brutal embestida contra los cluniacenses, falta de la más elemental caridad cristiana. Fuera de los cistercienses no hay salvación.

No es verdad que la belleza sensible sirva de mediación para llegar a la verdadera Belleza. Este mundo no es símbolo de nada. Es pura trampa para los que se dejan seducir por sus encantos. En los monasterios cistercienses,

27. Confesiones $13,21,30$.

28. Kenneth Clark, L'art du paysage, René Julliard, Paris 1962, 2-3.

29. Cit. por García M. ColombÁs, La tradición benedictina, IV, 2. El siglo XII, Ediciones Monte Casino, Zamora 1994, 544; cf. ÍD., La tradición benedictina, IV, 1. El siglo XII, Ediciones Monte Casino, Zamora 1993, 182-185. cit., 543.

30. Cit. por García M: Colombás, La tradición benedictina, IV, 2. El siglo XII, edic. 
y en esto era fiel al espíritu de los fundadores, no toleraba imágenes sagradas, ni ornamentaciones, ni vidrieras policromadas, ni nada que pudiera ser grato a los sentidos. Todo eso podía ser útil a los analfabetos, que son incapaces de entrar dentro de sí mismos. A los monjes les sobra con una cruz de madera pintada, quizá con la imagen de Cristo y otras escenas de su vida, y un candelabro de hierro. Una casa de oración, y esos son los monasterios, no necesita más. Es el despojamiento más absoluto, la desnudez, la pureza de líneas llevada al límite, que, huyendo de la belleza, se convierte, sin embargo, en una de las formas artísticas más bellas. "La estética de la pobreza pretende limitarse a lo necesario y no conservar más que las formas funcionales sencillas [... porque] solamente a través de la renuncia el hombre podrá alcanzar el amor espiritual"31. Lograr la poesía en su desnudez total fue el anhelo más profundo de Juan Ramón Jiménez: "¡Oh pasión de mi vida, poesía / desnuda, mía para siempre!"32. ¿Hay belleza más alta y más intensa?

Pero como ha advertido Georges Duby ${ }^{33}$, los monasterios del Císter que nosotros admiramos están ya embellecidos, construidos cuando los cistercienses, "los pobres de Cristo", vivían como rentistas y grandes señores, y la pobreza de los orígenes era tan sólo un bello recuerdo en las crónicas ${ }^{34}$. Según él, sólo en Vauclair está la verdadera mirada del Císter.

Esta aversión a la belleza la practicó incluso con su hermana (apoyado por todos sus hermanos, cistercienses como él), a la que, a fuerza de desaires, la obligó a desfigurarse el rostro y a entregarse sin descanso a oraciones y ayunos hasta quedar tan horrible, que su marido, que terminó ingresando también en Claraval, consintió que entrara en el Císter. "Cuando reflexiona sobre la hermosura, se torna intratable"35.

Cuenta el carmelita Martín de san José que, viajando en cierta ocasión con fray Juan de la Cruz, pasaron cerca de unos edificios grandiosos. Los viajeros se desviaban a contemplarlos. Le sugirió a fray Juan desviarse también ellos, pero éste le contestó: "Nosotros no andamos por ver, sino por no

31. André VAuCHEZ, La espiritualidad del occidente medieval, Ediciones Cátedra, Madrid 1985, 127.

32. Antolojía poética, Editorial Losada, Buenos Aires $1958^{2}$, 254. Vino primero pura es el primer verso.

33. San Bernardo y el arte cisterciense, Taurus Ediciones, Madrid 1983, 140.

34. Cf. García M. Colombás, La tradición benedictina, IV, 1. El siglo XII, edic. cit., 264-280.

35. José JimÉNEZ LozANo, Retratos y naturalezas muertas, Editorial Trotta, Madrid $2000,19$. 
ver"36. No hay que andar desparramado por las criaturas, sino concentrado en sí mismo, absorto en Dios, piélago sin fondo. La más leve distracción es inadmisible, ni siquiera durante el tiempo que se tarda en rezar un credo. "Nunca deje derramar su corazón, aunque sea por un credo"37. Todo lo demás es complacerse en el placer por sí mismo, servir a dioses extraños.

Hay, pues, que renunciar a los sentidos, purificarlos, mortificarlos o darles muerte, cerrar esas ventanas a la realidad, tapiarlos, encerrrarse dentro de uno mismo, emparedarse ${ }^{38}$. Ahí, dentro de uno mismo, habita la verdad. Ahí, en la tiniebla, fosforecerá la luz, y, calladas todas las criaturas, se oirá, como un susurro tenue, la voz de Dios. Hay que huir de este mundo que pasa, trascenderlo, y habitar por la contemplación, ya en esta vida, en aquel otro imperecedero; vaciarse de todo y de todos, también de uno mismo, para que solo Dios ocupe nuestro espacio interior. Hay que purificar las potencias del alma de todo el arrastre que los sentidos han dejado en ellas; matar todo afecto humano, empezando por el de los más allegados, que es el más peligroso, hasta desnudarse casi "de este corporal velo" 39.

\section{ABSORCIÓN DE LA REALIDAD}

En contra de esta doctrina, hay que decir que los sentidos nos son absolutamente necesarios. Son nuestros primeros órganos de conocimiento, nuestras antenas de contacto con la realidad. Sin ellos no hay mundo exterior, pero tampoco interior, nada. La pobreza o riqueza de éste depende de la pobreza o riqueza del mundo exterior que cada uno absorba. Son los sentidos, en definitiva, los que nos hacen ricos o pobres humanamente. Todo comienza en ellos. No, fray Juan, no. Aquí estamos para ver y oír y tocar y oler y gustar. "Ojos, oídos, tacto son la hacienda del espíritu; el poeta, muy

36. Cit. por Jean Baruzi, San Juan de la Cruz y el prblema de la experiencia mística, edic. cit., 302 .

37. San JUAN DE LA CRUZ, Dichos de luz y amor, $\mathrm{n}^{\circ} .145$.

38. El emparedamiento, más practicado por mujeres que por hombres, fue la forma extrema de esta renuncia a los sentidos., la exacerbación de la huida del mundo. "Desemparó el mundo Oria, toca negrada, / en un rencón angosto entró emparedada, / sufrié gran astinençia, vivié vida lazrada /. [...] Quiso seer la madre de más áspera vida, / entró emparedada de çeliçio vestida" (Gonzalo de BERCEO, Vida de santa Oria, vv-77-79 y 81-82, Clásicos Castalia, Madrid 1981, 97. Cf. María del Mar GraÑa Cid, Emparedamientos femeninos y vida diocesana entre los siglos XIV y XVI, en XX Siglos 11 (2000) 65-69.

39. Fray LuIS DE León, Poesía completa, 14, v. 32 (Al apartamiento), edición de José Manuel Blecua, Editorial Gredos, Madrid 1990, 201. 
especialmente, tiene que empezar por una amplia cultura de los sentidos. Platón, de quien gentes distraídas aseguran que fue un fugitivo del mundo sensible, no cesa de repetir que la educación hacia lo humano ha de iniciarse forzosamente en esta lenta disciplina de los sentidos, o, como él dice: ta eroticá. El poeta tendrá siempre sobre el filósofo esta dimensión de la sensualidad" 40 .

Para ser nosotros mismos necesitamos lo otro que nosotros, especialmente a los otros. Necesitamos absorber realidad, mucha y muy variada realidad. Realidad física y realidad humana. Realidad presente y realidad pasada. Succionando sus jugos, no sin ellos, podremos proyectar el futuro y hacerlo presente. Necesitamos vivir la vida con intensidad, somorgujarnos en ella, dejar que nos penetre y nos posea, que vaya revelándonos sus diversos lados, su haz y su envés, sus olas de superficie y sus corrientes profundas.

La juventud, sobre todo, necesita ejercitarse en esta disciplina imprescindible. "La juventud necesita dejarse influir. Una mocedad hermética que no se deja penetrar por formas ejemplares de vida renuncia a formarse el tesoro interior de ideas y emociones que han de operar luego como magníficos resortes orgánicos. Biológicamente, parece haber sido prevista la juventud como una etapa de enérgica absorción. El mozo tiene que dejarse transir hasta el eje mismo de su persona por toda ejemplaridad [...]. Quiera o no, en virtud de una ley inexorable, el organismo se va obliterando, formando un caparazón defensivo que ampara lo que haya dentro, pero impide todo nuevo ingreso del exterior. Conviene, pues, llegar a la madurez con los sótanos del alma pertrechados" 41 .

Azorín fue un maestro ejemplar de esta apertura a la realidad. Por eso sigue enriqueciéndonos a sus lectores. Absorbió con avidez, también con amor y, a veces, con dolor, la realidad de España, sus paisajes, sus pueblos y ciudades, su presente y su pasado, sus libros - iqué gran maestro de literatura!-, su riquísima variedad humana, y nos la comunicó en libros de prosa rompedora, precisa, placentera, luminosa. "Azorín nos enseñó no sólo a escribir sino a mirar. Escribió de esa manera porque miró de esa manera" 42 . "Después de absorber la realidad, dice recordando el ama y haz lo que quie-

40. José Ortega y Gasset, Los versos de Antonio Machado, en Mocedades, EspasaCalpe, Madrid 19747, 134.

41. ID., El deber de la nueva generación argentina, en Meditación del pueblo joven, Espasa-Calpe, Madrid 1964, 31-32.

42. Andrés Trapiello, Los nietos del Cid. La nueva Edadd de Oro de la literatura española (1898-1914), Editorial Planeta, Barcelona 19972, 190. 
ras de san Agustín, después de recogerlo todo, haz lo que quieras. Es decir, mira, escucha, atiende, vive, espera, recuerda, imagina y haz lo que quieras [...]. Recoge en silencio, como la hormiga en su hormiguero recoge su nutrimento, las observaciones pacientes que hayas hecho. Y cuando en tu cerebro, en tu sensibilidad esté todo depositado, haz lo que quieras. Y haz lo que quieras porque fatalmente, sin que tú te des cuenta, pondrás en tu obra ese cimiento de cosas concretas, sin el cual la obra se desmorona"43.

¡El cimiento de cosas concretas! Sin él, toda elucubración es quincalla, vaciedad, teoría en el aire. La abstracción es necesaria, pero edificada sobre la realidad, ceñida a ella. Necesitamos reflexionar sobre la realidad. Reflexionar es distanciarse de ella, pero sin romper los hilos que a ella nos unen. La vida precisa ser pulimentada, ascendida al mundo diáfano de los conceptos, acendrada, liberada del espacio y del tiempo. Pero hay que meditar partiendo de ella, y, sin perderla de vista durante la meditación, volver a ella, zambullirnos de nuevo en su torrente ${ }^{44}$. Lo contrario es andar a cintarazos con fantasmas, y nada hay más triste que dejar la realidad, que es, por espectros, que no son. Oigamos este aviso: "Cabeza meditadora, / iqué lejos se oye el zumbido / de la abeja libadora! / Echaste un velo de sombra / sobre el bello mundo y vas / creyendo ver, porque mides / la sombra con un compás. / [...] De la mar al percepto, / del percepto al concepto, / del concepto a la idea / -joh la linda tarea!--, / de la idea a la mar. / ¡Y otra vez a empezar!"45. Quien ha pertrechado bien su interior de cosas concretas nos enriquece y nos abre siempre a dilatadas lejanías. Quien no ha sido capaz de hacerlo por falta de inteligencia, o quien, por cerrazón, se ha encastillado en sí mismo, ateniéndose a lo recibido, a lo rutinariamente repetido, nos empobrece el horizonte y nos lo estrecha. Sepamos distinguir a unos y a otros, y frecuentemos a los primeros. Es esta, la de enriquecernos o no, una cualidad fácil de advertir en los libros desde las primeras páginas. Respiremos el aire limpio de aquellos, aire tonificador de serranía. Dejemos que entre por nuestros poros y llene de tesoros nuestro interior.

Abrámonos a nuestra circunstancia, a la próxima y a la lejana; poseámosla. Que ninguna nos sea ajena. Cada sentido es una ventana abierta a la realidad. No la cerremos. Aprendamos a reconocer los estímulos, a diferenciar sus matices. Un entomólogo, un ornitólogo, un ciego, un catador de vinos, un perfumista no tienen un sentido de la vista, oído, tacto. gusto $u$

43. Cit. por Julián MARÍAs, Azorín, "con amor y sin engaño ", en $A B C$ 2-3-92, 3.

44. Cf. José VEGA, Acción y centemplación, en Estudio Agustiniano 31 (1996) 299-332.

45. Antonio Machado, Campos de Castilla, en Poesía y Prosa, edición crítica de Oreste Macrí, Espasa-Calpe / Fundación Antonio Machado, Madrid 1989, II, 596. 
olfato distinto del de los demás, pero han aprendido a usarlo, a recibir por él informaciones que a los demás les pasan desapercibidas. Han aprendido a distinguirlas e identificarlas. Es sabido el intenso desarrollo sensorial que tenían los primitivos, y conservan aún en parte los aborígenes. También los orientales nos llevan en esto una gran ventaja. Viven más en contacto con lo inmediato que nosotros, los occidentales. Recuperemos el uso de los sentidos, disfrutemos de la vida, de la realidad inmediata, del presente, del instante. Carpe diem, quam minimum credula postero, "disfruta el día de hoy, no confíes lo más mínimo en el mañana"46. Frente al cristianismo de la desencarnación y negación, en el que fuimos formados, recuperemos el cristianismo de la encarnación y afirmación de lo creado. Cuidemos, sobre todo, el trato personal, la convivencia, también con las personas del sexo opuesto, la rica experiencia de la vida.

Es verdad que el hombre es futurizo, orientado hacia el futuro; que está siempre viniendo de él. Viniendo de él, haciendo real lo proyectado, no quedándose en los proyectos. Vivir en el futuro o en el pasado es soñar despierto, andar de sonámbulo por la vida, dejar escapar neciamente el presente, que es lo único que realmente existe. Escribió Pascal: "Que examine cada uno sus pensamientos. Los encontrará afanándose en el pasado o en el futuro. Casi nunca pensamos en el presente; y si pensamos en él, sólo es para tomar de él luz con que construir el futuro. Jamás es el presente nuestro fin. Así jamás vivimos, pero esperamos vivir, y preparándonos a ser felices, es inevitable que no lo seamos nunca"47. En una de las fábulas de Esopo, se habla de un perro que, mientras atravesaba un río con un trozo de carne en la boca, se vio en el espejo de las aguas. Por coger la carne que en ellas veía, soltó la que llevaba, y se quedó sin la una y sin la otra. Por ir por la que no era, se quedó sin la que era. Aviso para caminantes. De uno de sus personajes dice Azorín que era "coleccionista de crepúsculos, espiador de matices, gustador de imperceptibles sensaciones"48. Como él. "Ponerse en la ventana y contemplar ahora, ignorado de todos, el cielo azul; pasar la mano por este tablero de pino y sentir una honda y dulce voluptuosidad ${ }^{49}$; escuchar este gemido y estas palabras de dolor de un hombre

46. Horacio, Odas 1, 11. Cf. Blanca GonZÁlez de EsCANDón, Los temas del "Carpe diem " y la brevedad de la rosa en la poesía española, Barcelona 1938.

47. Pensées, texte integral de Pensées établies, classées et annotées par Jean Steinmann, Club de Libraires de France 1961, 58. Está en los pensamientos ordenados por Pascal bajo la palabra vanité.

48. Blanco en azul, Espasa-Calpe, Madrid 19644, 138.

49. Sobre un "tablero de la mesa" tiene Jorge Guillén un delicioso poema titulado "Naturaleza viva", sabiamente comentado por Dámaso Alonso, Cf. Jorge Guillén, Aire 
pobre, y sentir por primera vez toda la grandeza y la profundidad del dolor humano. Percibir, en fin, como de nuevo, la vida. Y de nuevo el tiempo. Y de nuevo la eternidad"50. La lectura de los buenos escritores, Azorín, Gabriel Miró, Juan Ramón Jiménez, etc., es una buena preparación para aprender a ejercitar los sentidos y gozar de ellos, porque todos ellos toman parte en sus descripciones 51 .

\section{MEMORIA DE LAS SENSACIONES}

Hemos visto cómo en los últimos capítulos del libro $\mathrm{X}$ de las Confesiones Agustín nos cuenta sus esfuerzos por purificar la memoria, por borrar de ella las huellas que las sensaciones le han dejado, para que toda ella quede iluminada por el sol de la Verdad. Todo esfuerzo es poco en esta tarea, pero el esfuerzo humano de nada sirve si no está ayudado por la gracia de Dios. "Mi esperanza es tu misericordia", repite como un estribillo ${ }^{52}$. Los espirituales de todos los tiempos hablan de desnudez, renuncia, despojamiento, desasimiento, vacío, desamparo, mortificación, desarrimo, purgación, purificación, aniquilación, nada... "Mientras que poco a poco / borro de la memoria cuanto impreso / dejó allí el vivir loco"53.

Hay que destruir los recuerdos mediante el olvido, no recibir nuevas sensaciones, negarse a sí mismo para que el agua de la gracia limpie las rocas interiores del chapapote de las criaturas, hasta que sólo sean puro reverbero del Sol divino. A purificar la memoria de las "aprehensiones" de los sentidos y de la imaginativa dedica san Juan de la Cruz los 15 primeros capítulos del libro 3 de la Subida del Monte Carmelo. Hay que aniquilar la memoria, reducirla a nada, de forma que no quede en ella "noticia ni rastro" de cosa alguna, sino que se quede "calva y rasa", dice en el c. $1, \mathrm{n}^{\circ} 4$.

nuestro. I. Cántico, Barral Editores, Barcelona 1977, 50; Dámaso Alonso, Poetas españoles contemporáneops, en Obras completas, Editorial Gredos 1975, 704-706.

50. Azorín, Pueblo, Espasa-Calpe, Madrid $1967^{3}, 21$. Sobre la sensibilidad y la estructura sensorial del mundo, cf. Julián MARÍAS, Antropología metafísica, Ediciones de la Revista de Occidente, Madrid 1973, 119-134.

51. En J. BEAUGRAND, Manuel pratique de composition française, Classiques Hachette, Paris 1966, I, 57-119, encontrará el lector numerosos ejercicios sobre cómo ejercitar los distintos sentidos y cómo utilizar las sensaciones en una descripción. Véase también Luis Alonso ScHÖKEL, El estilo literario. Arte y artesanía, Ega-Mensajero, Bilbao 1995, 199-221.

52. Cf. Confesiones 10, 29, 40; 10, 32, 48; 10, 35, 57.

53. Fray Luis de LeÓn, Poesía completa 14, vv. 26-28 (Al apartamiento), edic. cit., 201. 
Sólo así podrá el alma unirse a Dios ${ }^{54}$. Pero ¿habrían podido los místicos escribir sus obras, tan sensitivas algunas de ellas, tan sensuales e incluso tan eróticas, si hubieran practicado este raimiento de las sensaciones? "El aire de la almena, / cuando yo sus cabellos esparcía, / con su mano serena / en mi cuello hería, / y todos mis sentidos suspendía"55. Estos versos y otros tan sublimes como estos no se han podido escribir sin el gozo de los sentidos, sin el gozo enajenado del tacto en este caso, y sin su placentera reviviscencia en la memoria. Mas dejemos estas visiones y vengamos a la nuestra.

"La memoria de una sensación remota aglutina alrededor de tal sensación, en el artista, un mundo de otras sensaciones y de distintas ideas"56. Las sensaciones quedan en nuestra memoria como lucecitas que alumbran nuestro pasado, cada vez más hundido en las sombras, y nos hablan de hechos pretéritos y de personas que se resisten a desaparecer. Aquellas nubes trashumantes con sus bordes incendiados por el tibio sol de invierno en su ocaso, cambiando caprichosamente de formas para asombro del niño aquel que las contemplaba embebido, mientras su corazón se llenaba de la música íntima de las cosas y de nostalgia de lo infinito. Los tesos aquellos con el verde presado de las viñas o con las uvas ya maduras para las faenas del lagar, y el sonido aquel de las esquilas de los rebaños en la tarde apacible, y la canción aquella, que venía de lejos, y se adentraba en el corazón llenándolo de pena. Los rostros aquellos de personas nunca olvidadas, que acompañan con su presencia las horas del vivir. La mano aquella del padre en la fría noche de invierno, oscura como boca del lobo, en el pueblo solitario, dando calor y protección, o los besos aquellos de la madre, sal de la tierra en su bondad cristiana. La voz aquella, que en la soledad del campo, en una mañana luminosa, junto al caño de agua corriente y cristalina, nos llamó por nuestro nombre y nos sentimos ser. El perfume aquel de los huertos en plena eclosión primaveral y el repicar aquel de las campanas, a prima hora, que anunciaba mercado en Benavente. El rumor aquel del río, inolvidable, que se acercaba y se alejaba en el silencio de las noches aquellas de invierno, en las que el cielo azul, azul, azul era un campo de estrellas par-

54. Cf. María Jesús MANCho DuQue, El símbolo de la noche en san Juan de la Cruz, Ediciones Universidad de Salamanca 1982, 225-297; ID., Palabras y símbolos de san Juan de la Cruz, Fundación Universitaria Española / Univrsidad Pontificia de Salamanca, Madrid 1993, 211-232.

55. San JUAN DE LA CRUZ, Canciones del alma, en Vida y obras de san Juan de la Cruz, BAC, Madrid $1978^{10}, 401$.

56. Azorín, Memorias inmemoriales, XLV, en Obras selectas, Biblioteca Nueva, Madrid 1982, 1245. 
padeantes, lámparas del gran templo cósmico. El aroma aquel de las mieses en las eras, inconfundible, y el gozo aquel de la chiquillería montada en el aparvador como coronación de la trilla. La alameda aquella -de los álamos vengo, madre-, con sus álamos acariciados suavemente por la brisa, hojitas temblorosas con su haz verde y su envés blanquecino... ¡Qué delicia entrar, de vez en cuando, en el huerto de las sensaciones pretéritas y gozarlas una a una, en pequeños sorbos, o, a veces, todas juntas! El mundo nos entra por los sentidos. Es nuestra riqueza. ¿Por qué renunciar a ella? ¿Por qué dejar la memoria "calva y rasa" de recuerdos?

Ningún otro estímulo como los olores para evocar viejas sensaciones dormidas en la memoria. "Cuando el ambiente está fuera cargado de humedad y el aire es frío, es cuando los olores, más que otro estimulante cualquiera, hacen resurgir, en los poseedores de memoria de sensaciones, los viejos estados espirituales. Cada ciudad tiene su olor y cada casa también el suyo. No todos los países y todas las civilizaciones odoran lo mismo"57.

El sabor de una magdalena mojada en una taza de té desencadenó en el protagonista de $A$ la recherche du temps perdu, de Marcel Proust, el recuerdo vívido, sensorial, de los días felices de su infancia. Hay quienes tienen una memoria especial para las sensaciones. "Estados espirituales remotos vivían con autenticidad en la subconsciencia de don Pablo. No podían ser evocados a voluntad, como evocamos a nuestro talante los paisajes y la música. De pronto, inesperadamente, una voz, un ruido, un incidente cualquiera, le hacían experimentar al caballero, con prodigiosa exactitud, con exactitud angustiadora, la misma sensación que quince, veinte o treinta años antes había experimentado" 58.

\section{EL VOCABULARIO DE LAS SENSACIONES}

El vocabulario de las sensaciones es decepcionante. No se descubren en él matices. Ocurre en general con todo lo humano, a diferencia de lo que ocurre en cualquier campo léxico de cosas y animales domésticos. El arado, la bodega, el ganado porcino, la apicultura, la matanza, el fuego, la indumentaria y tantos otros campos rebosan de diferencias y precisio-

57. Azorín, Doña Inés, edición de Elena Catena, Clásicos Castalia, Madrid 1973, 201.

58. ÍD., ib., 116.

59. Cf. César Hernández Alonso (Coord.), Diccionario del castellano tradicional, Ámbito Ediciones, Valladolid 2001. 
nes. Abundante es también el campo de los insultos ${ }^{59}$. En cambio, en lo referente a las sensaciones, todo es tosco, dicho a bulto, a ojo de buen cubero ${ }^{60}$.

"Advierte el corto número de vocablos que para designar las diversas percepciones de los sentidos tenemos. En cuanto a los olores, no pasamos de olores fuertes, débiles, aromáticos, fétidos, nauseabundos, ambrosíacos, aliáceos, amoniacales... Te estoy repitiendo el vocabulario de un cierto autor. En lo que respecta a los sabores, no es tampoco copioso el léxico: tenemos las calificaciones de dulce, salado, ácido, acerbo, amargo, acre, seco. Las resumimos todas groseramente diciendo que unos sabores son agradables y otros desagradables. Más pobre todavía es lo que atañe al oído: ni siquiera existe para las sensaciones auditivas un término que las abarque, con propiedad, todas. Decimos sonido; añadimos ruido, si el sonido es desapacible. La voz amada, que nos halaga o nos consuela, ies, por ejemplo, un sonido? El latido remoto del can en la noche callada, latido que resuena en nuestro espíritu y lo conmueve, ¿es sonido?"61.

\section{LA VISTA}

\subsection{La perspectiva}

La vista es el sentido del mundo en cuanto tal, de la mundanidad. Por ella no sólo nos son presentes las luces, los colores y las formas, sino también su contexto, su red de relaciones mutuas. Dentro del campo visual, nunca vemos una cosa sola. Vemos siempre una cosa destacando sobre otras; una cosa a la que atendemos, y un fondo, ámbito u horizonte desatendido, dentro del cual la vemos. Y todo ello lo vemos estructurado, en perspectiva.

Yo, esté donde esté, estoy siempre aquí (y ahora, pero esto requiere otro análisis). Lo otro y los otros están ahí o allí, a mi derecha o a mi izquierda, arriba o abajo. Todo hace referencia a mí, está en relación conmigo, visto desde mí. Y lo mismo les pasa a los demás. Cada uno tiene su aquí, distinto del mío y del de los otros, siempre distinto. Mi aquí y el suyo se excluyen mutuamente. Es decir, el mundo se me presenta a mí en una

60. Cf. Julio CASARES, Diccionario ideológico de la lengua española, Editorial Gustavo Gili, Barcelona 19772; Manuel ALVAR EzQUERRA, Diccionario ideológico de la lengua española, Bibliograf, Barcelona 1995.

61. AzORÍN, Memorias inmemoriales, XLV, edic. cit., 1245. 
perspectiva inexorablemente distinta a aquella en que se te presenta a ti. El mundo se le presenta a cada uno en una perspectiva única, en la suya, que excluye las de todos los demás.

Resulta de esto que no sólo yo soy yo y tú eres tú, sino que mi mundo es mío, exclusivamente mío, y el tuyo es tuyo, exclusivamente tuyo. Tu proyecto vital y el mío, tu vocación y la mía, por muchos rasgos que tengan en común, son siempre individualísimos, únicos, irreductibles, lo más individual que tenemos. Estamos fuera el uno del otro. Pero también están fuera nuestros mundos, por muchas coincidencias que haya en ellos. Yo estoy en mi mundo y tú en el tuyo. Irremediablemente. Nos "somos radicalmente forasteros"62. Y esto que ocurre en nosotros dos ocurre en todos los hombres. Por eso es tan difícil la convivencia.

Verdades de perogrullo, archisabidas, en las que no hay por qué insistir, dirá alguno. Pero si tan conocidas son, ¿por qué las olvidamos a diario? Pues si esto es así, es evidente que la realidad es plural, y, por consiguiente, que nuestra actitud mental debe ser el pluralismo, no la unidad; el reconocimiento y aceptación de la realidad plural. Una educación con los pies en la realidad tendrá que partir de este hecho, y convertir lo que en sí es dificultad y limitación, fuente continua de desavenencias y encontronazos, en sostén y empuje de una convivencia mutuamente enriquecedora. ¿Cómo? Aprendiendo a respetarse mutuamente, a respetar las opiniones de los demás por muy desacertadas que nos parezcan; a entrar en ellas y ver las razones en que se sustentan; a dejarse fecundar por ellas; a dilatar la propia perspectiva; a corregir, si es preciso, nuestras convicciones, o, incluso, a abandonarlas; a encontrarnos realmente con los otros. En suma, aprendiendo a dialogar. Entonces, en el corazón mismo de las discrepancias, encontraremos no pocas coincidencias. Encontraremos que podemos relacionarnos, respetarnos, comprendernos, amarnos, colaborar juntos en la obra de un mundo mejor y más humano. Así se vive hoy unánimes y concordes, unánimes en la pluralidad y concordes en el desacuerdo. Lo demás son utopías, que dejan siempre a sus espaldas la realidad, con frecuencia bañada en sangre ${ }^{63}$. Si los otros tienen opiniones distintas a las mías, en temas trascendentales o en temas cotidianos, no es porque sean perversos, aunque lo podemos ser todos. El error no está en la voluntad como dijeron

62. José ORTEGA y GASSET, El hombre y la gente, Espasa-Calpe, Madrid 1972, 68.

63. Cf. José VeGA, El diálogo, en Estudio Agustiniano 37 (2002) 319-359.

64. Si el error está en la voluntad, sólo por el pecado puede alguien estar en él. Consentir el error es consentir el pecado, ser cómplice de él. Hay, pues, que perseguir el 
san Agustín y santo Tomás de Aquino entre otros ${ }^{64}$. La Inquisición, que fue un gravísimo error histórico, no tuvo su origen en la maldad de los señores inquisidores, aunque en ellos hubo de todo. Hay opiniones distintas porque hay distintos ángulos de visión, distintas perspectivas. Cada uno ve la realidad fragmentariamente, una mínima parte de la realidad. Se impone dialogar desde esos fragmentos en busca de las partes complementarias, abandonada toda posición de superioridad. Si yo no dudo de estar en la verdad, tampoco debo dudar de que lo estén los demás, aunque sea una verdad muy distinta a la mía 65 . De lo contrario, está demás el diálogo.

Esto no es caer en el relativismo, ni es decir que vale todo, que todas las opiniones valen lo mismo, que da lo mismo tener una opinión que otra como afirman los posmodernos. El sermón de las bienaventuranzas y un manual de terrorismo no son intercambiables. Tampoco quiere decir que hay que carecer de convicciones y arrimarse al sol que más calienta. Donde no hay convicciones, habrá cháchara, pero no diálogo. El diálogo exige tener convicciones antes, en y después de él. Esto lo único que quiere decir es que los demás son también personas, y, por el mero hecho de serlo, tienen una dignidad inalienable y el derecho a expresar sus opinones, en las que es posible que haya verdad; a expresar la realidad que ven y tal como la ven; a vivir en ella dentro del mutuo respeto. Entre el diálogo actual que hay entre las iglesias cristianas y las guerras de religión y excomuniones mutuas del pasado, la elección no es dudosa.

\subsection{La mirada}

Mas volvamos a la mirada, al gozo de mirar (los espirituales del pasado se rebullen, airados, en sus tumbas). Gozos de la vista se titula un hermoso libro de poemas de Dámaso Alonso66. "Goza, goza el color, la luz y el oro", nos exhortan Garcilaso y Góngora. Aprendamos a mirar, a mirar y a ver. A contemplar el paisaje, las obras de arte, la belleza, el resplandor mágico de la belleza, allí donde se dé; también, y sobre todo, en la mujer ${ }^{67}$. No es fácil. "Yo no he acabado nunca de ver una hoja", decía Goethe. Porque vemos

error, extirparlo. La Inquisición está justificada con todos los medios que hagan falta, incluida la tortura y la pena de muerte.

65. Cf. Thierry TILQuin, Pour une confrontation des convictions, en Lumen Vitae 52 (1997) 125-132.

66. En Obras completas, Editorial Gredos, Madrid 1993, X, 401-458.

67. Cf. Julián MARÍAS, La educación sentimental, Alianza Editorial, Madrid 1992, 243252; ÍD., La mujer y su sombra, Alianza Editorial, Madrid 1987, 93-105. 
desde nuestra cultura, desde nuestros sentimientos y deseos, desde nuestros recuerdos, desde lo que somos y pretendemos ser. El que ve no es el ojo, sino el hombre a través del ojo; el hombre desde su experiencia vital. Con razón Husserl enseñaba a practicar la epojé o reducción, a poner entre paréntesis nuestros prejuicios y saberes adquiridos para alcanzar el fenómeno en sí mismo. Hay que aprender a practicarla, hay que aprender a liberarse de lo que nosotros ponemos en la realidad al observarla, aunque de antemano sabemos que, en su totalidad, es imposible. El observador se introduce, inexorablemente, en el fenómeno observado. Nuestros sentidos filtran la realidad y nuestro cerebro la crea en gran parte. Una taza de té no es lo mismo para un español que para un chino. Con el rayo que viene de la realidad a nuestra pupila, se mezcla el rayo que va de nuestra pupila a ella. No somos pupilas pasivas, y con nuestro ver activo podemos alterar profundamente la realidad. "Saldré al campo a mirar una encina, a ver si consigo ver qué es lo que veo cuando veo una encina" 68 .

De ordinario, resbalamos sobre las cosas, pasamos distraídamente a su vera, sin concederles la mirada que nos están suplicando. En vez de ver, preferimos guiarnos por lo que se dice, dejarnos llevar por la corriente. Aprendamos a mirar, a ejercitar asidua e intensamente nuestra mirada, a no excluir de la realidad lo que no coincide con lo que nos interesa, a no poner en ella lo que en ella no está. A diario caemos en estos riesgos, sobre todo en nuestro trato con las personas. Aprendamos a mirar limpios de prejuicios. Aprendamos a desplazar nuestra mirada en torno a los objetos para recoger el mayor número posible de aspectos suyos, a convertir en obra de arte el más pequeño detalle, a hacer de un puñado de flores una ikebana. Una gota de agua que resbala de un cántaro... ¡una nonada!; pero recogida por la retina de Velázquez y llevada al lienzo, se ha quedado convertida para siempre en obra de arte en El aguador. Son los artistas, con su mirada zoom, los que nos enseñan a ver lo que desde siempre teníamos ante nuestros ojos, pero quizá nunca habíamos reparado en ello. La retama ha quedado ennoblecida para siempre en los versos de Leopardi. Que nada escape a nuestra mirada. Aprendamos a ver los objetos en conexión unos con otros, en sus mutuas reverberaciones, haciendo de cada uno centro del universo, llevándolo a plenitud de significado ${ }^{69}$. Ver así es comprender, pensar

68 José Antonio MARINA, Teoría de la inteligencia creadora, Editorial Anagrama, Barcelona $19956,142$.

69. Cf. José Ortega y Gasset, Meditaciones del Quijote, comentario por Julián Marías, Ediciones de la Universidad de Puerto Rico / Revista de Occidente, Madrid 1957, $11-59$ y $219-280$. 
con la mirada. No pienses, mira, decía Witgenstein. "¡Ay río de Sevilla, / qué bien pareces, lleno de velas blancas / y ramos verdes!", cantó Lope de Vega. Desde entonces, el Guadalquivir es ya otro río. Así veía Cervantes, así veía Velázquez. Dos pupilas abiertas al mundo, golosas, insaciables, penetrantes. Ahí está su obra, viva, perenne, inacabable, alimentando a generaciones y generaciones sin fin. Sin una mirada así, no hay obra que valga la pena. Ni arte, ni literatura, ni pensamiento. ¡Ni pensamiento! Ni teología, ni moral, ni espiritualidad. Nada de nada. Lo primero es ver, absorber realidad. Lo demás son fantasmas.

Ver: aquí comienza todo, siempre que se tome esta palabra en su más rigurosa literalidad. No se debe hablar de ningún tema si antes no ha sido visto detenidamente. Una vez visto con ojos escrutadores, lo que de él se diga tendrá, inevitablemente, la transparente evidencia del manantial en la roca. Y esto, la evidencia, la claridad, la visualización, debe ser la primera cualidad de lo que se dice. No anduvieron desorientados los griegos al designar las distintas operaciones del conocimiento con términos vulgares que se referían al ver o mirar. Idea es la vista, el aspecto exterior que presenta una cosa, en especial su aspecto bello ${ }^{70}$. Aún hoy, con frecuencia decimos "ver" por "entender". Conocer una realidad es verla. En lo que ya no anduvieron tan acertados fue en moldear la teoría del conocimiento según lo que creían que tenía lugar en el acto de la visión. También en este punto hay que deshelenizarse.

\subsection{Las artes visuales}

"La experiencia me ha enseñado que para el estudiante de arte ver es, a veces, más difícil que creer"71. Si esto es así para los que estudian arte, es facil adivinar qué verán los profanos. Y, sin embargo, la dimensión artística es esencial en el desarrollo de la persona, tanto el saber el lenguaje de las distintas artes como la práctica de una o varias de ellas. El arte auténtico es siempre excesivo, va más allá de los límites, más allá de lo humano. Con su mirada amorosa, el artista desvela el rostro oculto de la realidad, su aura de luz, y lo deja plasmado para siempre en signos que nos hablan en silencio. Hay que aprender a descifrar su lenguaje, prepararse para el gozo de la pura contemplación, para disfrutar el esplendor de la belleza. Poder deleitarse contemplando el Moisés, de Miguel Ángel, La rendición de Breda, de Ve-

70. Cf. Charles Mugler, Dictionnaire historique de la terminologie optique des grecs, Librairie C. Klincksieck, Paris 1964.

71. Joshua C. TAYLOR, Aprender a mirar. Una introducción a las artes visuales, Ediciones La Isla, Buenos Aires 1985, prólogo a la primera edición, IX. 
lázquez, o la mezquita de Córdoba es resultado de una educación progresiva del gusto estético. Hay que familiarizarse con la historia del arte, aprender a distinguir las épocas y los estilos, saber elegir el punto de vista para la contemplación. Hoy se forman largas colas cuando hay exposiciones de arte, y los museos suelen estar llenos de visitantes. Pero ¿cuántos saben disfrutar realmente de las obras artísticas, comulgar con ellas, recuperar, en lo posible, la intuición del autor, discernir entre lo valioso y lo banal, entre lo auténtico y la bisutería de mercado? Hay que aprender todo eso, pero elemento imprescindible de la formación artística es la contemplación inmediata de las obras, sentir directamente su emoción, ese estremecimiento que recorre el cuerpo cuando se está en presencia de la verdad artística. Los textos literarios fueron escritos para ser leídos, no para ser analizados, ni para hacer con ellos ejercicios gramaticales. De la misma manera, cuando se quiere gozar de un cuadro, de una escultura o de una catedral están de más los intermediarios. Cuantos menos elementos extraños se interfieran, mejor. La costumbre, sin embargo, suele ser la contraria. "El hecho se constata al comprobar cómo el espectador de un cuadro primero mira la placa con el nombre del autor para, a partir de sus conocimientos, admirar y extasiarse delante de él. Así, su valoración no tiene en cuenta la obra sino el autor"72. A tal contemplador le daría lo mismo si el cuadro estuviera falsificado o fuera una copia. Hay que hacer exactamente al revés. "A ambos lados de la obra literaria [dígase lo mismo de toda obra de arte] hay dos intuiciones: la del autor y la del lector [o la del espectador]. La obra es registro, misterioso depósito de la primera, y dormido despertador de la segunda. La obra supone esas dos intuiciones, y no es perfecta sin ellas. Exagerando la dirección de nuestro concepto, diríamos que la obra principia sólo en el momento en que suscita la intuición del lector, porque sólo entonces comienza a ser operante"73. Iluminado por este conocimiento intuitivo, de una intuición totalizadora, el espectador, o el lector, puede entregarse, si a tanto llega, a analizar minuciosamente la obra, a desenredar su tejido y escudriñar sus entrañas, bajo la guía, nueva Beatriz, de esa luz primera.

Y ¿qué decir del arte cristiano? Llanto y desolación, lágrimas a tragos. Ya en el barroco, pura ostentación del poder de la Iglesia, que lo dominaba todo, se banalizó el sentimiento religioso, que, "en pleno triunfo de la cato-

72. Juan Ramón TRIADó, Las claves de la pintura, Editorial Ariel, Bacelona 1986, 3.

73. Dámaso Alonso, Poesía española, Editorial Gredos, Madrid 1957, 38; en Obras completas, Editorial Gredos, Madrid 1989, IX, 29-30.

74. José Jiménez LozAno, La luz de una candela, Editorial Ántrhopos, Barcelona $1996,79$. 


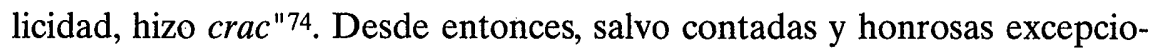
nes, se propaga la estampita popular, los cromos piadosos, los sagradoscorazones de tan dudoso gusto estético, la mojigatería san-sulpiciana, el chafarrinón de la basílica de Lourdes. El arte religioso se convierte en sinónimo de ñoñería y afectación, concesión a las emociones más elementales de las gentes, arte basura. Y sin embargo... "Estos, Fabio, ¡ay dolor!, que ves ahora / campos de soledad, mustio collado, / fueron un tiempo Itálica famosa". Ya lo creo que lo fueron. Ahí está el arte cristiano de otros siglos. Ahí está el éxito de las exposiciones que se hacen con ese arte. Pero no nos engañemos. A esas exposiciones se va a ver arte, es decir, lo que se dio a sus autores por añadidura, no lo que ellos pretendieron: expresar y suscitar la fe. Incluso los que son cristianos, van a ver arte, no a vivir la fe. Esas obras no expresan la fe de hoy. Si la fe dio origen a distintas expresiones artísticas a lo largo de los siglos, respondiendo a las necesidades del hombre de cada época, es necesario que hable, también hoy, al hombre actual. El arte cristiano, en la modernidad, ha brillado por su ausencia ${ }^{75}$. ¿No será que la fe ha sido reacia a la modernidad, y que ella misma está brillando también por su ausencia? Urge formularla de nuevo en nuestras categorías. En Occidente, un cristianismo premoderno no tiene nada que hacer ${ }^{76}$.

\subsection{El rostro}

Aprendamos a ver, muy especialmente, el rostro de las personas; a ver e interpretar su expresión; a ver su realidad interior. Y en el rostro, los ojos, en los que se manifiesta, en forma eminente, la dirección y la intensidad de lo que sale de dentro ${ }^{77}$. Lo sumo a lo que una mirada puede llegar es a mirar en otros ojos, que también miran. "El ojo que ves no es / ojo porque tú lo veas; / es ojo porque te ve"78. Se dice, y es verdad, que la cara es el espejo del alma. "Yo prefiero decir que la cara es la persona misma, vista, es decir, presente"79. El rostro es el texto, unas veces sincero, otras falsificado, pero siempre fascinante, en el que se expresa la persona. Conocer su alfabeto,

75. Cf. José VEGA, A propósito de las "Edades del hombre", en Religión y Cultura 35 (1989) 183-204.

76. Cf. Andrés Torres QeIRUgA, Fin del cristianismo premoderno, Editorial Sal Terrae, Santander 2000.

77. Sobre las diferentes clases de mirada, cf. José ORTEGA y GASSET, Sobre la expresión, fenómeno cósmico, en El espectador, Espasa-Calpe, Madrid 1966, VII y VIII, 43. ÍD., El hombre y la gente, edic. cit., 81-82 y 99-101.

78. Antonio Machado, Nuevas canciones, en Poesía y prosa, edición crítica de Oreste Macrí, Espasa-Calpe / Fundación Antonio Machado, Madrid 1989, II, CLXI, 626.

79. Julián MARías, Antropología metafísica, edic. cit., 158. 
que varía según las culturas, es inaplazable. Pero así como las palabras no tienen sentido sino en su contexto, así también los gestos faciales. Fuera de contexto, son siempre polisémicos. Un texto que no es estático, dado de una vez para siempre, sino cambiante. Se escribe sobre la marcha, está siempre aconteciendo. "Cada persona suscita las expresiones de los demás, las estimula, abre, refrena, orienta [...]. No olvidemos que cada uno recibe en buena proporción lo que ha hecho brotar en los demás y ve las facetas que ha alumbrado" 80 .

En la cara se hace visible la realidad de la persona, que es siempre sexuada, varón o mujer. Cuando esto no ocurre, se experimenta cierto malestar y desorientación. En cambio, cuando en ella esplende la condición masculina o femenina, se establecen automáticamente relaciones de polaridad, que pueden originar una convivencia sexuada satisfactoria (sexuada no es sexual). Más aún: en la cara me encuentro con la persona en su unicidad irreductible, con tal persona y no otra. En ella se me hace inteligible, asisto a su hacerse. Veo el borbollar de su estado actual de ánimo, su expresión (desdén, altivez, amor, cólera, tristeza, alegría, despecho, odio, entusiasmo, apocamiento...), y, lo que es más interesante, su proyección hacia el futuro, su significado. La cara mira hacia delante, hacia el porvenir, de donde estamos viniendo. Saber leer el rostro de las personas es, lamentablemente, una disciplina desconocida. Vemos los gestos, y leemos con relativa facilidad la expresión; pero el significado, el quién de la persona, se nos escurre. Y, sin embargo, la contemplación del rostro es el camino más séguro para conocer a las personas.." Cuando hablamos con alguien, estamos viendo su alma como un mapa marino abierto ante nosotros. $\mathrm{Y}$ elegimos lo que se puede decir y excusamos lo que se debe callar, esquivando así los arrecifes de aquella alma cuya figura nos parece palpar con unas manos místicas que de nuestra mente brotan. Y no es sino una prueba más de que esta intuición es constitutiva de la psique humana el hecho de que unos la posean en mejor medida que otros y haya ciegos y zahoríes en la percepción del alma ajena"81.

Gran observador fue Josep Pla. El precipitado de sus miradas no es nada halagüeño, pero ¡cuánta verdad hay en él! "A veces, dice, me paseo por las calles con el exclusivo objeto de mirar la cara de los hombres y de las mujeres que pasan. La cara de los hombres y de las mujeres que han

80. ÍD., Mapa del mundo personal, Alianza Editorial, Madrid 1993, 33.

81. José ORTEGA Y GASSET, Sobre la expresión, fenómeno cósmico, en El espectador, edic. cit., VII y VIII., 42-43. Cf. Karl BÜHLER, Teoría de la expresión, Alianza Editorial, Madrid 1980. 
pasado de los treinta años, ¡qué cosa más impresionante! ¡Qué concentración de misterios minúsculos y oscuros, a medida del hombre; de tristeza venenosa e impotente, de ilusiones cadavéricas arrrastrando años y años; de cortesía momentánea y automática; de vanidad secreta y diabólica; de abatimiento y resignación ante el Gran Animal de la Naturaleza y de la vida! Hay días en que invento cualquier pretexto para hablar con la gente que voy encontrando. Les miro a los ojos. Es un poco difícil. Es la última cosa que la gente se deja mirar. Me espeluzna ver la escasa cantidad de personas que conservan en la mirada algún rastro de ilusión y de poesía -de la ilusión y de la poesía de los 17 años-. En la mayoría de los ojos se ha difuminado todo impulso hacia las cosas inconcretas y graciosas, gratuitas, fascinadoras, inciertas, apasionantes. Las miradas son duras o mórbidas o falsas, pero totalmente arrasadas. Son miradas puramente mecánicas, desprovistas de sorpresa, de aventura, de imponderable" 82 .

\subsection{Dos amigos de mirar}

Gran amigo de mirar fue Ortega. Él, como Goethe, se consideraba del linaje de los que "de lo oscuro hacia lo claro aspiran", y con Goethe repetía que "el órgano con que yo he comprendido el mundo es el ojo"83. La penetración luminosa de su mirada es uno de los rasgos que todos los discípulos resaltan en él. "Sus ojos -he pensado- eran claros; penetrantes, pero sin dureza; no atravesaban como el acero, sino como la luz. Ortega hacía profesión, vocación mejor, del mirar"84. "Veía la flecha en el aire y sorprendía al pájaro cuando se dispone a emprender el vuelo"85. Mirando hizo Ortega su filosofía. "Yo sólo ofrezco modi res considerandi, posibles maneras nuevas de mirar las cosas. Invito al lector a que las ensaye por sí mismo, que experimente si, en efecto, proporcionan visiones fecundas"86. La perspectiva no es un añadido a la realidad, sino su organización intrínseca. Por

82. El cuaderno gris, El Mundo, Madrid 1999, 41-42.

83. El hombre y la gente, edic. cit., 36-37.

84. Julián MARÍAS, Ortega, amigo de mirar, en Acerca de Ortega, Ediciones de la Revista de Occidente, Madrid 1971, 105.

85. María Zambrano, Don José, en Ínsula 119 (1955), 7. Josep Pla, en una de sus escapadas a Madrid para conocer a los intelectuales madrileños, fue con Zulueta a la clase de Ortega. Quedó impresionado por "la voz prodigiosa", pero, sobre todo, por sus ojos "de una movilidad sorprendente que siguen las incidencias de la vida mental del profesor con una fidelidad absoluta, como siguen sus ademanes, sus repudios o preferencias [...]. En nuestras latitudes son los ojos nuestro instrumento dialéctico más decisivo, son quizá nuestra dialéctica misma" ( cit. por José ORTEGA SPOTTORNO, Ver y mirar, en El País 15-2$88,11)$.

86. Meditaciones del Quijote, edic. cit., 33 y 241-242. 
esto se mantuvo fiel a su propio punto de vista, a su concreta situación histórica de español y europeo del siglo XX, y desde él filosofaba. "El Espectador [Ortega] no niega por negar; posee una idea harto exacta y clara de su misión, que no es precisamente empobrecer el mundo, sino todo lo contrario: llenarlo de novedades y perspectivas inéditas, desde las cuales se multipliquen las reverberaciones de las cosas. Una idea nueva es una nueva posición, sesgo o ángulo, desde donde la realidad adquiere una perspectiva insospechada; un nuevo punto o sistema de referencia que nos impone, por lo mismo, la necesidad de alterar las ecuaciones con que definimos las cosas. El Espectador se desplaza ágil en torno a la realidad [...] para obtener de las cosas y de los valores el mayor número de vistas posible"87.

Ortega miraba una y otra vez; miraba de cerca y de lejos, a derecha e izquierda; miraba el haz y el envés, desde fuera y desde dentro; multiplicaba gozosamente las perspectivas; apresaba en su retina los paisajes de superficie, y hendía, entusiasmado, los que duermen en las profundidades, nunca antes de él navegados, como de los mares explorados por los portugueses cantó Camões. Regalaba luego generosamente sus visiones a sus discípulos, o las vertía en una prosa cincelada, coruscante, cuyo rasgo más saliente es su irresistible poder de visualización. El lector no sólo asiente a lo que en ella se le dice, sino que ve que las cosas que en ella se dicen son así, evidentes ${ }^{88}$. Ortega le seduce con el embrujo de su estilo; le obliga a acompañarle en el movimiento prensil de su mirada, a asistir al nacimiento mismo de los temas, a verlos en sus conexiones, a seguir sus trayectorias en el pasado, a atalayar su futuro. Lo que para otros es nonada, la caza, por ejemplo, o el bosque de El Escorial, se transustancia en su meditación, y se convierte en tema de gran calado filosófico y dilatado enriquecimiento humano. Es lo que él llamaba salvación de la circunstancia.

A seguirle nos llama. "Quien no sienta la soberana fruición de ver lo real, sin necesidad de más; quien no se sienta atraído por ese entusiasmo visual -Platón llama a los hombres científicos filoceámones, los amigos de mirar-, que no ejerza profesión propiamente intelectual"89. Si acudimos a su llamada, aprenderemos a ver, y nuestro mundo interior se enriquecerá con los humildes tesoros hallados en el mundo exterior, a cuya vera había-

87. Manuel García MoRenTe, La pedagogía de Ortega y Gasset, en Escritos pedagógicos, Espasa-Calpe, Madrid 1975, 75.

88. Cf. Julián MARÍAs, Mi primer curso de Ortega, en Acerca de Ortega, edic. cit., 208210. ÍD., Las "Notas" de José Ortega y Gasset, íb., 212-214; María Zambrano, íb. íb.

89. José ORTEGA Y GASSET, Reforma de la inteligencia, en Apuntes sobre el pensamiento, Ediciones de la Revista de Occidente, Madrid 1975, 75. 
mos pasado ciegos, y "vendremos a encontrarnos todos en una nueva vida, que sería nuestra inédita y peculiar manera de festejar el paso de nuestras almas por la Historia" 90 .

Gran amigo de mirar es Julián Marías. Se lo debe a su maestro Ortega. "A los dieciocho años, dice, yo era un muchacho pensativo, meditabundo, siempre dispuesto a rebotar de las cosas hacia mis adentros y ensimismarme. [Un día Ortega le llevó a pasear por la Gran Vía madrileña.] Cuando se es joven, me dijo, hay que abrir bien los ojos; hay que mirar, mirar, mirar; hay que llenar la retina de impresiones frescas, porque luego no se puede ya. Sentí el impacto de sus palabras, caí en la cuenta del riesgo, me esforcé por mirar, primero, y luego el mirar fue ya mi delicia: los rostros humanos -la única cosa de que me fío-, las gentes por la calle, las ciudades, los países, las cosas más humildes, las mudas cosas que están en nuestro próximo derredor. Mirando se hacen las dos terceras partes de toda filosofía que no sea -en una forma o en otra- escolástica"91.

Aquí radica su pasión por el cine. Porque si algo distingue al cine es su visualidad, su capacidad para hacer visibles realidades complejas, escurridizas, difíciles de descubrir fuera de la pantalla; de hacer evidente lo que es oscuro fuera de ella, en el entramado de la vida humana. Y el cine le ha proporcionado muchos de sus hallazgos de antropología metafísica. "Muchas de las ideas que he elaborado filosóficamente han nacido de una sesión de cine", ha confesado en más de una ocasión.

El día en que dos terceras partes de la dogmática y de la moral y de la espiritualdad y de la liturgia y de la predicación... se hagan mirando, viendo la realidad, comenzarán a interesarles a los hombres, porque habrán dejado de ser teología zombi, y hablarán de ellos y les hablarán a ellos. No sé si llegaremos a tiempo.

\section{EL OÍDO}

\subsection{El sentido del ambiente}

El oído es el sentido del ambiente. Nos rodean sonidos, nos envuelven. Claros o confusos, cercanos o lejanos, vivos o apagados, suaves o estridentes, unas veces en tropel, otras separados. Nos asedian desde todas las direcciones. Vienen en ondas concéntricas, trayéndonos el lugar de donde pro-

91. Julián Marías, Ortega, historia de una amistad, en Acerca de Ortega, edic. cit., 102. Cf. Joseph H. Silverman, Julián Marías en California, en Ínsula 119 (1955) 13. 
ceden, aunque no podamos precisar su punto exacto. Un ciego sabe desde dónde le hablan.

\subsection{La palabra}

Aristóteles y santo Tomás de Aquino dieron preferencia al sentido de la vista sobre los demás. La vista es el más espiritual, el más perfecto de los sentidos $^{92}$. Así es en nuestra cultura, pero no siempre fue así. Decir hombre es decir sociedad. Cuando caemos en la cuenta de nosotros mismos, estamos ya habitados por los otros, que nos habitan especialmente por la palabra. Somos comunicación ${ }^{93}$. Los pueblos primitivos daban prioridad al oído, al grito silábico. Su cultura era oral, la escrita no existía. Y al oído dan prioridad las religiones. Es la palabra hablada, no la escrita, la palabra proclamada en comunidad, la que transmite lo sagrado, la que, con sus resonancias, abre espacios a la presencia de lo numinoso. De ahí la importancia de manejarla adecuadamente para que su eco resuene en la intimidad de los oyentes, y se produzca en ellos el temblor de lo sagrado, fascinante y pavoroso. Inhorresco et inardesco ${ }^{94}$. Palabras y silencios, silencios y palabras, son igualmente necesarios en esta alta función de propiciar la experiencia de lo divino. La poesía experimental de nuestros días ha vuelto a descubrir la fuerza creadora del sonido, las "células fonéticas", como las llamó Hugo Riemann. Así, por ejemplo, Juan-Eduardo Cirlot, tan lleno de la cábala, de la cultura celta y de las antiguas literaturas germánicas ${ }^{95}$.

\subsection{Escuchar la naturaleza}

¡Qué delicia escuchar, extasiado, la risa del agua tropezando en las guijas, la quejumbre de una fuente en la umbría, a la hora del crepúsculo, el oleaje de un bosque agitado por el viento, el rumor del mar que galopa hacia la playa, sofrenado o furioso! "Embriaguez de oír: ruiseñor, piano, I mar, selva, viento, multitud, noticia"96. "Y un horizonte de perros / ladra

92. Santo Tomás de Aquino, Suma teológica I, 78, 3.

93, Cf. José VegA, La comnuicación, en Estudio Agustiniano 34 (1999) 107-142.

94. "¿Quién será capaz de comprender? ¿Quién podrá explicarlo?¿Qué es aquello que me ilumina y hiere mi corazón sin lesionarlo? Me siento horrorizado y enardecido. Horrorizado por mi desemejanza con él, enardecido por mi semejanza" (San Agustín, Confesiones 11, 9, 11).

95. Cf. Juan Eduardo Cirlot, Bronwyn, edic. de Victoria Cirlot, Ediciones Siruela, Madrid 2001; Jaime D. PARRA, La forma generatriz y la experiencia de lo sagrado en la poesía de Juan-Eduardo Cirlot, en Ínsula 638 (2000) 8-11.

96. Dámaso Alonso, Embriaguez, del libro Hombre y Dios, en Obras completas, edic. cit., X, 384 . 
muy lejos del río"97. Para siempre han quedado en el cielo azul de nuestra memoria el río y la ladra, que se oye lejana allá en el confín, llenando de tristes presagios nuestro corazón. ¿Por qué no afinar el oído escuchando las voces de la naturaleza, el gran concierto de los muchos y muy variados sonidos con los que sin cesar nos regala? ¿Por qué no detenerse a escucharlo sosegadamente, y dejar que se nos adentre por los caminos interiores poblándolos de música y silencio, y de Dios? "Era en Numancia, al tiempo que declina / la tarde del agosto augusto y lento, / Numancia del silencio y de la ruina, / alma de libertad, trono del viento / [...] Súbito ¿dónde? un pájaro sin lira, / sin rama, sin atril, canta, delira, / flota en la cima de su fiebre aguda. / Vivo latir de Dios nos goteaba, / risa y charla de Dios, libre y desnuda. / Y el pájaro, sabiéndolo, cantaba"98. Ortega y Gasset nos ha dejado una descripción inolvidable del bosque de El Escorial, de sus luces y colores, de sus aguas que rumorean, de sus avecillas cantoras. Una meditación filosófica sobre lo visible e invisible del bosque, sus patencias y latencias u ocultaciones, su superficie y su profundidad, su mundo y su trasmundo, su pasado (huellas) y su futuro (posibilidades); sobre las impresiones que él recibe y las interpretaciones que hace. Una reflexión, no en abstracto, sino sobre un bosque concreto, sobre un bosque radicado en su vida, vivido. Una meditación que pone en práctica la razón vital, su innovación metódica más importante, antes de teorizar sobre ella. Porque lo primero es hacer las cosas y luego hablar de ellas. Primero es la práctica y luego la definición de lo que se está practicando. Porque, como dice el mismo Ortega, en un texto de clara ascendencia platónica, "quien quiera enseñarnos una verdad que no nos la diga: simplemente que aluda a ella con un breve gesto, gesto que inicie en el aire una ideal trayectoria, deslizándonos por la cual lleguemos nosotros mismos hasta los pies de la nueva verdad"99.

\subsection{La voz humana}

Pero lo más importante de la audición es la voz humana. La voz nos trae al otro en su individualidad, varón o mujer, niño, adulto o anciano. Sale

97. Fedrico GARCía LoRCA, Primer romancero gitano, Edición de Christian de Paepe, Espasa-Calpe, Madrid 1991, 205 ( La casada infiel) 444.

98. Gerardo Diego, Alondra de verdad, en Obras completas, Aguilar, Madrid 1989, I,

99. Meditaciones del Quijote, edic. cit., 80 y 285-305; Julián MARÍAs, Teoría de la realidad, en Ortega. Circunstancia y vocación 2, Ediciones de la Revista de Occidente, Madrid 1973, 219-242; ÍD., Antropología metafísica, Ediciones de la Revista de Occidente, Madrid $1973,67-68$. 
del cuerpo, pero es intrínsecamente biográfica, personal. Nos entrega la intimidad del otro, su alma, podríamos decir, si es que esta palabra conserva todavía algún significado, en otra dimensión que la del rostro. Aunque no le veamos, nos es suficiente oír su voz para representarnos su biografía, lo que de él sabemos. Da lo mismo que diga yo, abracadabra o hipotenusa, porque no es lo que dice sino su voz, con su tono y su timbre, la que nos le hace presente, la que nos dispara su biografía y nos la exhibe100. "La voz dice lo que quiere decir el rostro"101. Por eso la fonología, además de los fonemas y sus combinaciones en sílabas y palabras, estudia los prosodemas (acento, tono, cantidad, timbre). La voz es significativa, es palabra. Nos dice algo de algo o de alguien, nos lo interpreta. El oído es el sentido de la significación. "Todo el pensamiento, incluso el pensamiento solitario, está fundado en el lenguaje y, por tanto, en el oído"102. La convivencia, en cuanto comprensión, acontece auditivamente. Los sordos y los mudos viven vitalmente, aunque no sensorialmente, en un mundo auditivo, en el mundo interpretado por los que oyen y hablan, como los ciegos viven en el mundo vital de los que ven. Si todos fuéramos ciegos, sordos y mudos, nuestro mundo vital sería enteramente otro.

\subsection{La fe}

Y porque la voz nos trae a la persona, lo más íntimo de ella, el oído, que es el órgano de la persuasión, es también el sentido de la fe. "¿Cómo creerán en aquel a quien no han oído? ¿Cómo oirán sin que se les predique? [...]. Por tanto, la fe viene de la predicación, y la predicación, por la Palabra de Cristo"(Rom 10, 14.17).

Jesús no recibió tablas de la ley como Moisés, ni un libro dictado desde el cielo como Mahoma, sino el Espíritu de Dios. Ni escribió libros ni los mandó escribir. Lo único que encargó a sus discípulos fue: "recibid el Espíritu". Fue la palabra viva de su predicación, que brotaba del Espíritu, la que dio a los discípulos la buena noticia de Dios, su Padre y Padre nuestro. Fue la palabra viva de sus discípulos inmediatos la que transmitió su mensaje, y así sucesivamente hasta nosotros. Es la palabra viva de los que en él creemos la que debe seguir transmitiéndolo a través de la predicación y la catequesis. Palabra viva, nacida del Espíritu de Dios, que es la Vida, y se nos ha dado.

100. Cf. José ORTEGA y GASSET, El hombre y la gente, edic. cit., 137-141 y 195-196.

101. Julián MARÍAS, Antropología metafísica, edic. cit., 134.

102. ÍD., íb., 133. 
En la Edad Media, se usaba la expresión "las gentes del libro" o "las religiones del libro" para referirse a las tres culturas, religiones o castas, la judía, la cristiana y la musulmana, porque las tres se fundan en un libro revelado. En realidad, los cristianos no somos gentes del libro sino del Espíritu; no de un saber intelectual o moral, que no sobra, sino de una experiencia de vida o amor. Nuestro legado, el que recibimos y tenemos que transmitir, no es un texto sino el Espíritu. Los evangelios no se escribieron para suplantar al Espíritu; sino para ser proclamados en las celebraciones de la comunidad como expresión de ese mismo Espíritu. Los escritos son posteriores a la palabra hablada, que, a su vez, es posterior al Espíritu y de él dimana. Son posteriores a la palabra hablada, pero no pretendieron abolirla. El fundamentalismo no tiene cabida aquí. Los textos primeros remiten, a través de la comunidad intérprete, a Cristo resucitado. "Los teólogos cristianos no se encuentran a gusto hablando del cristianismo como religión el libro. En cualquier caso, es cierto que, si lo comparamos con el Islam, el equivalente del Corán no es la Biblia cristiana, sino el mismo Jesucristo como Palabra de Dios. Por lo demás, los textos fundamentales del cristianismo no envían solamente a una comunidad intérprete -como es el caso del judaísmo y del Islam-, sino a ese otro ausente y, sin embargo, presente; a saber, a Cristo resucitado, que coincide con todos los momentos de la historia y que permite que las escrituras fundantes se hagan espíritu y vida" 103 .

Así al principio y así siempre. Porque, también en la comunidad cristiana actual, lo primero debe ser la experiencia del Espíritu, y luego la predicación y la catequesis, que de ella brotan, y, finalmente, las formulaciones escritas, revisables siempre a la luz del Espíritu, que es siempre novedad, como Vida que es ${ }^{104}$. Las fórmulas escritas ahí se quedan, petrificadas, inmutables, idénticas a sí mismas para siempre; pero la vida cambia, fluye, mana incesante. "Sois una carta de Cristo redactada por ministerio nuestro, escrita no con tinta, sino con el Espíritu de Dios; no en tablas de piedra, sino en tablas de carne, en los corazones [...[. Fue Él quien nos capacitó para ser ministros de una nueva Alianza, no de la letra, sino del Espíritu. Pues la letra mata, mas el Espíritu da vida"(2Cor 3,3.6). En cualquier situación en que vivamos, los cristianos estamos siempre llamados a dar testimonio del Espíritu, del amor de Dios, del amor que hemos recibido de Jesucristo (Jn

103. Claude GEFFRÉ, La lecture fondamentaliste de l'Ecriture dans le christianisme, en Études, décembre 2002, 641.

104. Cf. Juan MATEOS - Fernando CAMACHO, El Hijo del hombre, Ediciones El Almendro / Fundación Épsilon, Córdoba 1995, 217-219. 
$1,16)$, de "lo que hemos visto y oído" (1 Jn 1,3). Esto debe ser lo primero, y luego, la palabra, oral y escrita, y la imagen

\subsection{Las artes auditivas}

Y de nuevo el arte. Hay que educar el oído para disfrutar de la música Recordemos la oda de fray Luis de León A Francisco Salinas: "El aire se serena / y viste de hermosura y luz no usada, / Salinas, cuando suena / la música extremada, / por vuestra sabia mano gobernada"105. ¡Inmejorable!

El alma de fray Luis, despertada por el "son divino" de la música de su amigo (la música de Salinas refleja, en cierto modo, la armonía del universo, que vive, como idea ejemplar, en la mente divina), recobra la luz de "su primer origen", y se eleva hasta Dios, "hasta la más alta esfera", hasta el empíreo, donde mora Dios, siguiendo el mismo movimiento que hemos visto en san Agustín: de los números (ritmos) mudables a los inmutables. Y allí oye otra música "no perecedera", "que es de todas la primera". No se trata, como ha demostrado Francisco Rico ${ }^{106}$, de la música de las esferas celestes, ni de la música del universo en su conjunto, "con que este eterno templo es sustentado", sino de la música divina, de la de Dios; de la música que hay en la mente divina, a la que responden, en "números concordes" con ella, las otras tres (la del universo, que incluye la de las esferas, la humana -la del alma y la del cuerpo- y la instrumental). Como en tantos otros textos, fray Luis funde armónicamente diversas tradiciones que estaban en el saber de su tiempo, haciendo de todas ellas un tejido inextricable y personalísimo. En esa música de Dios, además de la armonía ejemplar que hay en su mente, no hay que excluir los sones divinos que oyen las almas que han renunciado a "aqueste bajo y vil sentido". "Siguiendo una cierta dulzura, no sé qué oculto placer interior, como si de la casa de Dios sonara suavemente algún órgano [...], abstraído de todo ruido de carne y sangre, llegó a ella [...]. Allí hay fiesta perpetua. No se celebra en ella algo transitorio. Cuando cesa el mundanal ruido, se oye no sé qué sonido dulce a los oídos, procedente de aquella fiesta eterna [...]. El son de aquella fiesta acaricia al que pasea su mirada por la Iglesia y contempla las maravillas en la redención de los fieles, y arrebata al ciervo hasta las fuentes del agua"107. Ya no existe el cuerpo. Las criaturas han quedado en olvido. Pero que nadie se equivoque. Aquí se trata de un éxtasis musical, que nada tiene que ver con

105. Poesía completa, 3, vv. 1-5, edic. cit., 164.

106. El pequeño mundo del hombre, Editorial Castalia, Madrid 1970, 170-189.

107. San Agustín, Comentarios a los salmos 41, 9. 
lo que dicen experimentar los místicos. Fray Luis señala repetidas veces que él no lo ha experimentado, aunque lo desea. Es un éxtasis que desea compartir con sus amigos, "gloria del apolíneo sacro coro", gloria de las Musas, cuyo trato frecuentaban. Los otros, los éxtasis místicos, no son compartibles.

La teoría pitagórica de la música, que se enseñaba en el cuadrivio, y de la que fray Luis recibió lecciones de Salinas ("la especulativa"), le ha servido para describir, ¡con qué tino!, el vuelo de su alma hasta Dios escuchando la música que su amigo interpretaba en el órgano. ¿Creía fray Luis en esa teoría? Salinas, en su tratado De musica libri septem (1577), se refiere a la música celeste y a la del alma con un "dicuntur", según dicen. Son creencias de otros tiempos, de las que fray Luis se sirve de modo admirable para expresar su "ansia ardiente" de la vida inmortal, la misma que sentía cuando contemplaba "el cielo, de innumerables luces adornado"108. Todo lo sensorial, también la música, "todo lo visible es triste lloro". Hay que despojarse de todo ello. Pero la música de Salinas, la celebrada por fray Luis, no se dirigía al sentido, sino que, según el propio Salinas, era de aquellas que "levanta nuestro ánimo a la contemplación de las cosas celestes"109; de aquellas que "al bien divino / despiertan los sentidos, / quedando a lo demás adormecidos". Tal música, como la poesía de los profetas y la que a ella se acerca, "no es sino comunicación del aliento celestial y divino" para levantar, "con el movimeiento y espíritu de ella, los ánimos de los hombres" al cielo, "de donde ella procede" 110 .

Pero no hay por qué renunciar a la música que se dirige al sentido. La música hay que oírla, disfrutarla; dejarse llevar y traer, anegado, por su oleaje. Lo primero es sentirla, estar en ella, no en contemplaciones extrañas a ella por muy altas que sean; no usar de ella como trampolín para más altos deleites, sino gozar de ella por ella misma. Y su gozo no impide ser sensible también a aquella otra que nos llega de la casa de Dios.

Hay que educar el oído para la poesía, también para la prosa, que, como aconseja fray Luis de León, debe ser escandida, tener medida y número (ritmo). "Que el bien hablar no es común, sino negocio de particular juicio, así en lo que se dice como en la manera como se dice, y negocio que, de las palabras que todos hablan, elige las que convienen, y mira el sonido de ellas,

108. Poesía completa, 8, vv. 1-2 (Noche serena), edic. cit., 182.

109. Cit. por Fernando LÁzaro CARreter, El "ciego maravilloso", en $A B C$ 22-31990, 3; ÍD., La “Oda a Salinas", en Clásicos españoles. De Garcilaso a los niños pícaros, Alianza Editorial, Madrid 2003, 81-104.

110. Fray luis DE LEÓN, De los nombres de Cristo, l. II, Monte, edición de Cristóbal Cuevas, Ediciones Cátedra, Madrid 1977, 254. 
y aun cuenta a veces las letras, y las pesa, y las mide, y las compone, para que no solamente digan con claridad lo que se pretende decir, sino también con armonía y dulzura"111. Hay un oído musical y hay un oído linguiístico, un oído para la música del idioma. Hay que ejercitar los dos. Carecer de ellos es carecer de importantes dimensiones humanas.

Lo concreto exige siempre para ser percibido la colaboración de los sentidos, y el sentido del lenguaje es el oído. Hay que educarlo para el gozo de la poesía, que es donde se aprende, sobre todo, la música del idioma y sus funciones expresiva, sensorial e imaginativa. Dámaso Alonso ha escrito "sobre ese terrible encuentro lleno de presagios" del adolescente con la poesía, sobre el "brote de gusto por la poesía [...]. La vida no ofrece una estigmatización más fuerte que ésta. El impregnado ya queda aparte: Dios le ha señalado con su huella de fuego"112. Esta educación es más necesaria que nunca en nuestros días, en que el prosaísmo se extiende como un manchón corrosivo, y los impotentes hacen gala de ello.

$\mathrm{La}$ adolescencia es el momento irrepetible en que se despierta la sensibilidad, el momento propicio para aprender a saborear las producciones artísticas. $\mathrm{El}$ adolescente, todo poros, a poco que se le estimule el gusto por la poesía, beberá, complacido, su sabroso veneno. Y quien a esa edad no lo beba andará manco y reseco de por vida. San Agustín se arrepiente de haber llorado la muerte de Dido, que se suicidó de amores, leyendo los versos que Virgilio le dedicó al final del libro IV de la Eneida; versos que le obligaron a aprender de memoria: Lo cual prueba que el relato le hizo pupa, y le dejó fascinado para siempre. Así hiere la poesía, con heridas que nunca cicatrizan, y de vez en cuando manan. Si san Agustín tiene la sensibilidad tan aguda que tiene, y logra expresarla con tanta eficacia, ¿no se deberá a estos y a otros versos aprendidos en la niñez? También yo pequé, aunque sin llegar a sus extremos. En prueba de que no estoy arrepentido, he vuelto a leer estos maravillosos versos y a revivir antiguas emociones, que para mí van unidas a frías noches de invierno, de cielos altos y estrellados - "la luna emergiendo entre las nubes" (Eneida VI, 454)-, con el rumor del Esla al fondo. Y he vuelto a sentir el gozo lancinante de los hexámetros virgilianos.

Pero no sólo debe el adolescente leer y aprender poesías, sino que debe ejercitarse en el verso antes de practicar la prosa. "Tal es el orden natural en el desarrollo de la vocación literaria, y bien puede afirmarse que quien en su primera juventud no ha recibido con más o menos frecuencia la visi-

111. Ib., 1. 3, Dedicatoria, 497

112. Poesía española, edic. cit. 395; en Obras completas, edic. cit., IX, 331. 
ta del demonio poético necesitará doble esfuerzo para llegar a escribir prosa artística, ni tolerable siquiera [...]. Sutilizando y adelgazando el modo de decir, siempre más exquisito y selecto en la poesía que en la prosa, aprendiendo el verdadero valor de las palabras, y no el gastado y corrompido que les da el uso, buscando sin cesar con el entendimiento y con el oído nuevas formas y maneras de hermosura, es como se educa el verdadero poeta, cuando Dios puso en él la llama creadora e inventiva"113. El tiempo dirá si es o no poeta, pero el ejercicio del verso, si lo practica con ese "particular juicio" de que habla fray Luis y las condiciones señaladas por Menéndez Pelayo, le ayudará a escribir bien en prosa. Excitará su imaginación, y ¿qué es un escritor si no tiene imaginación?, le ayudará a descubrir el sentido auroral de las palabras, a sugerir en vez de decir y a decir sin decir, a encontrar los mejores vocablos, los que digan mejor lo que quiere decir, y a situarlos en el punto exacto para que lo digan con armonía, a fundir ritmo y expresión, de modo que fondo y forma sean inseparables.

Hay que aprender a percibir los factores sonoros del lenguaje, a saborear las palabras, a deleitarse en los textos literarios. De vez en cuando, conviene leer en voz alta a los buenos prosistas y poetas, dejar que su música nos acaricie el oído, regalarse en ella, escuchar los ecos que sus palabras producen en nuestro pozo interior. Hay muchos aspectos del lenguaje que escapan a una lectura silenciosa. Hay textos literarios que exigen ser escuchados. Lo exigen los textos antiguos, escritos para ser leídos en voz alta. Escapan, sobre todo, a una lectura silenciosa los efectos de las obras escritas para ser representadas, que exigen tono, énfasis, ritmo, modulaciones que subrayen los movimientos del alma. "A veces con gozo, esperanza y pasión, / a veces airado, con gran turbación. / Finge, leyendo, mil artes y modos, / pregunta y responde por boca de todos, / llorando y riendo en tiempo y sazón", escribió Alonso de Proaza, corrector de la impresión de La Celestina ${ }^{114}$.

\subsection{El silencio}

En música, el silencio, el "no sonido", es también música. El mundo acústico se compone de sonidos y silencios, y hay que educar el oído para

113. Marcelino Menéndez Pelayo, Discurso de contestación al ingreso en la R.A.E. de D. Francisco Rodríguez Marín, en Estudios y discursos de crítica histórica y literaria, V, C.S.I.C., Madrid 1942, t. X de la Edición Nacional, 40-41. Cf. Luis CernudA, Gustavo Adolfo Bécquer, en Estudios sobre poesía española contemporánea, Ediciones Guadarrama, Madrid-Bogotá 1957, 53-54.

114. Fernando de RoJAs y "Antiguo Autor", La Celestina, Editorial Crítica, Barcelona 2000,353 
percibir unos y otros. La palabra significa y significa el silencio, y tan importante es este como aquella. Se refuerzan mutuamente. En la comunicación, codificamos sólo una parte de lo que queremos decir y, a veces, ni eso. Se calló como un muerto, decimos, o quien calla otorga, o hablamos de silencio elocuente o de silencio administrativo. Hay quien dice más callando que otros hablando. Al transmitir un mensaje se dicen muchas más cosas de las que se dicen. Se dicen cosas que no se dicen porque se dan por supuestas, que se callan por sabidas -"lo que por sabido se calla"-, pero que están en el mensaje y actúan. Hasta tal punto actúan que el oyente o el lector son capaces de reconstruir el sentido a partir de esa codificación parcial o incluso nula. "Nuestros mensajes son como icebergs, en los que gran parte de lo que se comunica se halla sumergido, oculto, y donde sólo afloran a la superficie algunos aspectos. El mundo de lo ímplicito posee una importancia capital en nuestras comunicaciones" 115 .

Ha sido este un aspecto tradicionalmente descuidado en los estudios del lenguaje, hoy felizmente recuperado por la Pragmática. Indagar la dimensión silenciosa de los textos, descifrar lo que quieren decir sin decirlo, es una tarea que en los últinmos años ha producido ya frutos logrados. El uso del silencio como forma expresiva de lo inefable ha dado poesías espléndidas, pero es un recurso que está siempre en un tris de caer en la vacuidad o de encerrarse en un hermetismo seudointeligente. "Poesía es lo que no se entiende", dicen que dijo Valente. Esto es una parida. Las pitonisas se envolvían también en la calígine y pronunciaban sus oráculos indescifrables. Si fuera así, Nostradamus sería un gran poeta. Silencio, sí, pero que sea por exceso de claridad. Silencio que potencie la palabra.

Un buen orador y un buen lector saben cómo hacer expresivos los silencios, cómo convertir las pausas en silencios activos que refuercen los significados de las palabras, que den tiempo a los oyentes a captar su sentido sin aturdirlos con la velocidad ni aburrirlos con la lentitud. Un buen lector lee desde el silencio, oyendo musicalmente los textos, sus armonías y sus disonancias, dejando que las palabras resuenen en su interior, oyendo sus ecos en el pozo del alma; ecos que, enlazándose unos con otros, hacen ver el texto como lo que es: un tejido, un entramado de relaciones. Sólo entonces comienza la comprensión y el placer del texto. Un buen lector y un buen orador, que hablan desde el silencio, desde el manantial más soterraño de sus adentros, mueven a sus oyentes a crear espacios interiores, en los que

115. Salvador GutiérRez OrdóñEz, Presentación de la Pragmática, Universidad de León 1996, 30. 
también resuenen las palabras y los significados se adensen y se vuelvan luminosos, haciéndolos vibrar incluso corporalmente. Porque las palabras que brotan, henchidas, del silencio y caen en la tierra de un silencio acogedor penetran hasta los meollos y los conmueven, y se hacen vida y luz ( $\mathrm{Hb}$ $4,12)$.

Las celebraciones litúrgicas son un momento privilegiado para practicar estos distintos silencios los que en ellas participan. Desde el Concilio Vaticano II, "el silencio sagrado"116 es un elemento estructural de la liturgia, de modo que en las celebraciones tiene que haber momentos de silencio. Tiene que haberlos, sobre todo, en la celebración de la eucaristía. Silencio durante el examen de conciencia en el acto penitencial. Silencio para recogerse en oración cuando el sacerdote invita a orar. Silencio después de las lecturas y de la homilía para que la Palabra de Dios actúe como fermento. Silencio después de la comunión para adorar a Dios y darle gracias ${ }^{117}$. Son momentos para que cada uno se encuentre consigo mismo, sin máscaras, con los otros y con Dios, que habla siempre en silencio, como "susurro de una brisa suave" (1 Re 19,12), como "música callada y soledad sonora"118. El silencio es también participación activa y comunitaria en la celebración.

Bella teoría, pero ¡qué lejos queda la práctica! Sacerdotes que ignoran las más elementales nociones de pronunciación y entonación, que más que ayudar a los fieles a recogerse los duermen con su tono y elocución. "La voz ha de responder a la índole del respectivo texto"119. Lectores que leen con desgana y a los que nadie entiende. Homilías ininteligibles, con el desconocimiento más absoluto de la oratoria. Oyentes que no escuchan -a saber por dónde andan-, que no responden, o responden mascullando. Silencios que no se observan. Palabras y palabras y palabras. Saturación de palabras. ¿A qué hablar tanto de la interioridad si no se la practica? En una sociedad del ruido y la palabrería, ¿dónde hallar momentos de silencio si no es en las Iglesias?

¡Escuchar los silencios! Porque no hay uno sino muchos. El silencio de las catedrales mientras la tarde se muere en las vidrieras y en las naves se espesan las sombras. Recogerse en su soledad y sentirse uno con la multitud de los fieles que en ellas han vivido su fe, y en ellas han rezado desde sus penas y sus gozos. El silencio de una ermita románica, sola en la soledad

116. Sacrosanctum Concilium 30.

117. Ordenación general del misal Romano 23.

118. San JUAN DE LA CRUZ, Cántico espiritual B, canción 15.

119. Ordenación general del Misal Romano 18. 
de un cabezo, en la que el silencio mismo es ya rezo. El silencio del enjuto campo castellano, de horizontes infinitos, en el que una canción lejana, a la caída de la tarde, lo ahonda y lo adelgaza y lo hace sonoro. El silencio de una noche estrellada, en la que el corazón se llena de preguntas y sentimos, a nuestra vera, la compañía de fray Luis. "Oías el acorde / reservado a tu alma en el silencio / total de las estrellas"120. Ese acorde era para él Dios. El "maravilloso silencio", que tanto contentó a don Quijote, de la casa de don Diego Miranda, "que semejaba un monasterio de cartujos"121. El silencio fecundo de la estancia donde trabajamos, hecho de lecturas y reflexiones. ¡Voluptuosidad del silencio!

Necesitamos descubrir el silencio, el silencio exterior, pero, sobre todo, el interior. Lo necesitamos física y psíquicamente. Es parte consustancial nuestra. Cuando calla el alboroto de nuestro propio interior, la realidad comienza a decirnos su verdad. El hombre no descubre la verdad sino en la radical soledad de todo, también de sí mismo. Porque las cosas "no tienen voz, son máscaras mudas o si se quiere tienen una voz silente, una voz taciturna que sólo puede oír el hombre que se retira del mundo y renuncia a sí mismo. Entonces ese mundo silente de las cosas pone su silente voz en el solitario -que es el profeta, el pensador, el filósofo, en suma, el intelectual-, pone en él su voz taciturna como el ventrílocuo la sitúa en la figura de cartón que muestra al público. No es propiamente el pensador quien piensa y quien dice -son las cosas quienes en él se piensan y dicen a sí mismas-. La inteligencia, señores, es una operación de esencial ventriloquia. Este es el sentido que en Grecia tenía la palabra lógos, légein, decir"122. Necesitamos el silencio. Ciertamente, el hombre es una realidad de relación y necesita comunicarse con los demás (al no tenerlo en cuenta, los espirituales se equivocaron de medio a medio), pero la palabra que no sea acogida y devuelta en un clima de silencio vuela sin dejar huella. El silencio nos permite vivirnos mutuamente, sernos mutuamente realidades de rostro humano, habitarnos como personas. Y en ese mutuamente, en ese "entre", Dios, que nos sostiene a todos y en todos alienta, porque "en él vivimos, nos movemos y existimos" (Hch 17, 28). Necesitamos el silencio. Él, y sólo él, nos permite escuchar las voces interiores, las celestes y las infernales, las del "demonio

120. Jorge Gullé́n, Fray Luis de León, en Aire nuestro. III. Homenaje, Barral Editores, Barcelona 1978, 134.

121. Miguel de Cervantes, Don Quijote de la Mancha, parte II, c. 18, edición dirigida por Francisco Rico, Instituto de Cervantes-Crítica, Barcelona 19982, 776.

122. José ORTEGA Y GASSET, Sobre la razón histórica, Revista de Occidente en Alianza Editorial, Madrid 1979, 159-160. 
de los sueños" y las de "la voz querida", como las escuchaba Antonio Machado ${ }^{123}$. Necesitamos el silencio. Él da fuerza expresiva a las palabras. Gracias a él, podremos decir palabras esenciales, verdaderas. "Tal vez la mano, en sueños, / del sembrador de estrellas, / hizo sonar la música olvidada / como una nota de la lira inmensa, / y la ola humilde a nuestros labios vino / de unas pocas palabras verdaderas"124. La formación del carácter, decían los antiguos, comienza por el silencio. "¿No habíamos convenido que el silencio es el agua que modela a un hombre?"125.

\section{EL TACTO}

\subsection{El sentido de la realidad}

El tacto es el sentido de la realidad, el que nos revela la efectividad de las cosas. Es la instancia decisiva para comprobar si una cosa es real o mera apariencia. Al tocarla, confirma su realidad y la poseemos. Al tocar el bastón que aparece curvo en el agua, comprobamos que se trata de una ilusión óptica. Tocar fue la prueba que exigió el apóstol Tomás para saber si los otros discípulos habían visto al Señor o no. "Hemos visto al Señor en persona [...]. Como no vea en sus manos la señal de los clavos y, además, no meta mi dedo en la señal de los clavos y meta mi mano en su costado, no creo" (Jn 20, 25). El tacto "es la forma decisiva de nuestro trato con las cosas [...], el factor más perentorio en la estructuración de nuestro mundo"126.

En la negrura profunda de la noche, las cosas dejan de existir para nosotros. Sale el sol y se desperezan a la existencia. Se oculta de nuevo y otra vez formas y colores desaparecen. "¿Están? / Yo busco por donde estaban. / Desbrozadora de sombras, / tantea la mano. A oscuras / vagas huellas sigue el ansia. / De pronto, como una llama / sube una alegría altísima / de lo negro: luz del tacto. / Llegó al mundo de lo cierto. / Toca el cristal, frío, duro; / toca la madera, áspera /; jestán!"127.

123. Soledades, LXIII y LXIV, ib., 474.

124. ÍD., $i b$. LXXXVIII, $i b ., 487$. 154.

125. Andrés Trapiello, Los hemisferios de Magdeburgo, Pre-textos, Valencia 1999,

126. José ORTEGA Y GASSET, El hombre y la gente, edic. cit., 65.

127. Pedro Salinas, Don de la materia, en Seguro azar, en Poesías completas, Barral Editores, Barcelona $1975^{2}$, 124. Cf. Carlos FeAl DeiBe, Poesía y narrativa de Pedro Salinas, Editorial Gredos, Madrid 2000, 53-57. 


\subsection{Importancia del tacto}

Parece que el sentido del tacto fue el primero en aparecer y que los demás se derivaron de él por diferenciación. Los otros sentidos están situados, todos ellos, en la cabeza, mientras que el tacto se extiende por todo el cuerpo. Por eso es el que más corteza cerebral ocupa. Es el primero en aparecer y es el último en desaparecer. Sin los demás se puede vivir, pero no sin él. Con el tacto, únicamente con él, hizo Helen Keller los progresos que hizo, que tanto asombraron a quienes la conocieron ${ }^{128}$. "El tacto, ha escrito Francisco Umbral, es el camino directo al corazón de las personas y las cosas [...]. El tacto, sencillamente el tacto, nos da el contorno del alma de cada ser, muchacha o fuente, roca o flor, ángel o nube". El tacto es el sentido de la afectividad. En algunos momentos de la vida, en algunas etapas de su desarrollo y en determinados grupos de personas se ve claramente la importancia del tacto, y lo imprescindible que es en el desarrollo de la persona. Selecciono tres ejemplos: la infancia, los deficientes mentales y los momentos intensos de dolor o de alegría.

El niño necesita con necesidad de medio, perentoriamente, ser amado, sentirse en contacto cariñoso y tierno con alguien que le ame. Normalmente, son los padres biológicos quienes desempeñan esta función. El hombre nace antes de tiempo, sin estar terminado. Es un abortivo. No solo humana y personalmente, sino también biológicamente. Ni su sistema nervioso, ni su sistema inmunológico, ni el soporte enzimático están acabados cuando nace. Para que se desarrollen es de absoluta necesidad que el niño sea amado. El amor, lenta, pero inexorablemente, les va dando su acabado. $\mathrm{Y}$ es el amor el que va haciendo crecer al niño humana y personalmente. $\mathrm{La}$ afectividad, la confianza básica en la vida, la estima y aceptación de uno mismo, la inteligencia, la normalidad sexual, la aparición y el desarrollo de la subjetividad, la capacidad de amar... dependen, fundamentalmente, de haber sido amado en la infancia. Los estragos que hace su ausencia a la vista están. Las páginas de los periódicos están llenas de violencias y anormalidades de adultos, resultado, con muchísima frecuencia, de la falta de amor en su infancia. El niño necesita ser amado, pero no con amor posesivo, si es que a este se le puede llamar amor. Necesita caricias, besos, contacto físico tierno. Necesita que alguien le hable y le sonría. Alguien que esté físicamente presente. La televisión y la radio están de más en esta tarea. Somos, dice con razón Rof Carballo, hijos de la ternura. No se trata de considera- 
ciones piadosas, sino de verdades científicas, apoyadas en razones psicológicas, antropológicas y biológicas ${ }^{129}$.

$\mathrm{Y}$ esto que es tan claro en la infancia no nos es menos necesario después. Necesitamos ser amados. Necesitamos cariño, afecto, afecto humano, no sólo divino. Lejos, por supuesto, de las formas infantiles. La afectividad, como todo lo humano, tiene que madurar. "Sólo Dios basta"130, escribió santa Teresa. ¡Y un cuerno!. Somos personas, es decir, convivientes, intrínsecamente convivientes. Ser amados y amar: lo necesitamos para crecer humanamente ${ }^{131}$. Y esto es lo que hizo santa Teresa, aunque aconseje lo contrario.

El tacto es el sentido más desarrollado en las personas con alguna deficiencia mental. Su sensibilidad táctil es finísima, y, a través de ella, son capaces de establecer una comunicación de oro de ley. Nadie como ellos para percibir los dolores y las alegrías de las personas a las que aman. Por eso el trato con ellos ha de ser, sobre todo, a través del tacto, hasta tocar su alma, sus alegrías y sus angustias, sus ilusiones y sus desesperanzas, sus problemas, en suma. Pero, triste es recordarlo, en el pasado, un pasado todavía reciente, no fue así. En el pasado, prevalecía, sobre todo, una virtud, y no era precisamente la caridad, aunque otra cosa se dijera, sino la castidad. A los deficientes mentales se les reprimía toda expresión de afectividad, que la dieran o que la recibieran, por miedo a que se quemaran en la sexualidad en este mundo y en el infierno en el otro. $\mathrm{Y}$ así se los dejaba dormidos en su noche humana, apenas esbozos de personas ${ }^{132}$.

En el verano de 1996, una gran avenida de agua producida por una tormenta se llevó por delante, en un santiamén, un campamento en Biescas, dejando tras sí ochenta y seis muertos. La Cruz Roja Española creó entonces un grupo de apoyo psicológico a los damnificados por las catástrofes. Se comprobó que, en esos casos, no basta con la buena voluntad. Hay que estar allí para lo que cada uno necesite: escucharle, darle una tila, resolverle un papeleo, ponerle una mano en el hombro... Necesitan la presencia física, incluso el contacto, de alguien que sufra con ellos, que se compadezca de ellos. Ingmar Bergman confesó en cierta ocasión: "Cuando me siento demasiado angustiado, mi mujer, clavicordista (de origen estonio), notable intér-

129. Cf. Manuel CABADA, La vigencia del amor. Afectividad, hominización y religiosidad, San Pablo, Madrid 1994, 29-97, 117-119 y 143-150.

130. Poesías, en Obras completas, BAC, Madrid 19796, 514.

131. José VEGA, Sobre el "amor mutuo" de los cristianos, en Estudio Agustiniano, 31 (1996) 95-98.

132. Cf. José Ramón Amor, Ética y deficiencia mental, Universidad Pontificia de Comillas, Madrid 1995. 
prete de Bach, pone su mano sobre la mía, y me siento menos sólo"133. Cuando la pena o la alegría nos desbordan, necesitamos el contacto con otros para consolarnos de aquella o para comunicar esta, y recurrimos al abrazo y al beso, que rompen todas las barreras y llegan hasta los meollos.

\subsection{Los maestros de espiritualidad}

Pero no es esta la historia espiritual de Occidente. Una y otra vez, los obsesos sexuales, que tanto han abundado entre el clero, muy especialmente en los monasterios, le han corregido la plana a Dios, y han inculcado el horror al contacto de los cuerpos. No mirar, no oír..., pero, sobre todo, no tocar. ¡Uf, tocar! La barrera para aislarse de los otros quedaba establecida, y erizada de dificultades la relación con ellos. "Ninguna hermana abrace a otra, ni la toque en el rostro, ni en las manos, ni tengan amistades particulares, sino todas se amen en general, como lo mandó Cristo a sus apóstoles muchas veces, pues siendo tan pocas, fácil será de hacer [...]. Este amarse unas a otras en general y no en particular importa mucho"134. ¿Dónde mandó Cristo a sus apóstoles que se amaran en general y no en particular? Y ¿que será una amistad que no sea particular? Pero, en fin, se ve hacia qué terrenos apunta Santa Teresa y qué cosas malicia. Prohibido el amor humano por carnal; prohibida la amistad particular porque tanto detrás de aquel como de esta está emboscada la lujuria. El amor tiene que ser espiritual, puramente espiritual, y ¡cuántos ejemplos heroicos de este amor muestra la historia! Hay que amar a todos por igual. Da lo mismo que sean padres, hijos, hermanos, amigos... A todos hay que amarlos como se ama a los enemigos: como a hijos de Dios si lo son, o para que lo sean si no lo son. Hay que amar a todos en Dios, por Dios y para Dios, arrancando de cuajo cualquier otro afecto por noble que parezca ${ }^{135}$. Déme el lector su confianza y le ahorraré un montón de citas de todos los tiempos y lugares.

Esto mandó santa Teresa a sus monjas, pero de ella nos cuenta el P. Gracián que "reprendiéndola yo un día porque me quería tanto y mostraba tanto regalo, me dixo muy riéndose: Él no sabe que cualquier alma, por perfecta que sea, ha de tener un desaguadero; déjeme a mí tener este, que por más que me diga no pienso mudar del estilo que con él llevo" (la cursiva es

133. Cit. por Charles Moeller, Literatura del siglo $X X$ y cristianismo, Editorial Gredos, Madrid 1995, VI. Exilio y regreso, 136.

134. Santa Teresa DE Jesús, Constituciones, 6, en Obras completas, BAC, Madrid $1979^{\mathrm{a}}, 642$.

135. Cf. José VEGA, La convivencia según la Escuela Agustiniana española del siglo XVI, en Estudio Agustiniano 32 (1997) 298-317. 
mía). ¿Qué muestras de regalo le daba santa Teresa a Gracián para que este tuviera que reprenderla? Concuerda muy bien con esta anécdota el retrato que del temperamento afectivo de la santa hacen dos ilustres teresianistas: "La Madre revertía el alma a raudales, como si la llevase a flor de piel, y se volcaba con el torrente vital de su cuerpo sanguíneo"136. No pasemos por alto la palabra desaguadero, ¡tan expresiva!, que Gracián pone en boca de la santa. Santa Teresa tenía una afectividad desbordante, sanguínea, pero reprimida por la severidad de las leyes religiosas, y necesitaba darle salida, desaguarla, liberarse de la inundación que padecía, y lo hacía con Gracián, un real mozo, a quien amaba con amor particular -aunque otra cosa creyera ella-; con amor humano, sexuado, porque todo lo humano lo es (no hablo de amor sexual y quien no entienda la diferencia no sabe en realidad quién es el hombre); con grandes muestras de regalo, que a otros no daba. A san Juan de la Cruz, por ejemplo, aunque le estimara mucho y le tuviera por santo. Así era la santa, y no hay nada que reprocharle. Al contrario, ¡feliz ella! Pero el buen lector percibe enseguida la diferencia entre lo que mandaba y lo que practicaba, y esto sí que plantea problemas que no es el momento de dilucidar. ¿Habría tolerado en sus hijas semejantes muestras de afectividad, especialente con su queridísimo Gracián? Permítame el lector darle algunos textos, sólo algunos, de los muchos que se pueden entresacar de sus escritos.

"Otro día me dio una aflicción grande de verme sin él [...]. Ayudaba el ver que no hallo quien me dé alivio sino él, que lo más había de estar ausente, que me es harto gran tormento"137. "Después que vio a Paulo [así llamaba a Gracián] con ninguno tenía alivio ni contento su alma [...]. En estando sin Paulo, ni nada le satisface de lo que hace ni le parecía que acertaba ni aunque quería sujetarse a otro no podía"138. "Nunca terné mejores días que los que allí tuve con Paulo"139. La santa se queja de la llaneza que Gracián tenía en su trato con las monjas. En él era trato "de santo", pero no todos lo son, y "las que son ruines y maliciosas -como yo- querrían quitar ocasiones. Yo puedo tratar y tener mucho amor por muchas causas, y ellas no todas podrán. [Con ese trato no todas podrán guardar el tesoro de la castidad] que yo le digo cierto que tengo harto más miedo a lo que le pueden robar los hombres, que los demonios; y lo que me vieren decir y hacer a mí.

136. Efrén DE LA MADRE DE Dios y Otger STEGGINK, Tiempo y vida de santa Teresa, BAC, Madrid 1977, 550, $\mathrm{n}^{\circ} 323$.

137. Cuentas de conciencia, $44,2^{\mathrm{a}}$, ib., 472.

138. Cartas, 113, 5, ib., 776.

139. Ib., 158, 12, ib., 829. 
(porque entiendo con quién trato y ya por mis años puedo), les parecerá que pueden ellas hacer, y ternán razón.[...] He andado tan atada y mirada mirando en lo que el demonio las podía tentar conmigo [...]; he procurado encubrir de ellas mis imperfecciones [[...] y el amor que tengo a Paulo y el cuidado de él. [...] Puede hacerme la merced que le he suplicado de no leer en público las cartas que le escribo [...]. No será bien que las sepa nadie de hablar conmigo misma qué és esto, $\mathrm{u}$ vuestra paternidad a otras personas, aunque sea misma hermana; que como no querría que ninguno me oyese lo que trato con Dios ni me estorbase a estar con él a solas, de la misma manera es con Paulo..." 140 (la cursiva es mía). Hay aquí amor espiritual, sin duda, pero ¿sólo eso? ¿No hay aquí también afecto humano de dos personas de carne y hueso que se quieren? "Con fray Antonio no va nada, sino que tocándome tantico que toque a mi Paulo, no lo puedo sufrir, y de mí no se me da cosa"141. "Y lo que quieren a Paulo me cai harto en gracia, y que las quiera él bien me alegro, aunque no tanto. [...] Le querría estar siempre regalando y sirviendo"142 (la cursiva es mía). Le escribe la santa a la priora de Sevilla, María de san José, y le advierte que ande con cautela en su trato con Gracián, que hay ojos donde menos se piensa. Se diría que sólo ella podía tener ciertas efusiones. "De que vaya allá [el P. Gracián] mire, mi hija, lo que hace y que hay en casa quien la mire y en el peligro que hemos estado por estos descuidos con buenas intenciones"143. "En gracia me cai decir vuestra paternidad que le abriese el velo, parece que no me conoce : quisiérale yo abrir las entrañas. [...] Yo, pensando cuál querría más vuestra paternidad de las dos, hallo que la señora doña Juana [la madre de Gracián] tiene marido y otros hijos que querer, y la pobre Lorencia [santa Teresa] no tiene otra cosa en la tierra sino este padre"144. ¿No corre por estos textos cierto remusguillo de celos? Si no supiéramos que son de santa Teresa, ¿no las leeríamos como cartas de una enamorada? Ni juzgo ni condeno. Sólo trato de comprender. La doctrina está clara: hay que andar con tiento en las relaciones humanas, purificar todo afecto, purificar los sentidos, en especial la vista y el tacto, que el diablo está siempre al acecho, y "llevamos este tesoro en vasijas de barro" (2Cor 4,7), texto paulino que se aplicaba a la castidad. "Quéjanse que se rige vuestra paternidad por el P. Evangelista; también es bien que vaya con advertencia, que no somos tan perfectos que

140. Ib., 162, 1-4, ib, 832.

141. Ib., $233,10, i b ., 916-917$.

142. Ib., $155,12, i b ., 824$.

143. Ib., 309, 16, ib., 997.

144. $I b ., 120,4$ y $8, i b ., 785$. 
no podría ser tener con algunos pasión y con otros afición, y es menester mirarlo todo" 145 .

Si la santa se hubiera atenido a su doctrina, ¿se hubiera regalado tanto con Gracián? Las demás tenían que abstenerse, purificar sus afectos, "quitar ocasiones", no escandalizar "a las ruines y maliciosas", pero ella no, "por muchas causas". Ella podía "tratar y tener mucho amor, porque entiendo con quién trato y ya por mis años puedo". Las demás, no. No sabrían distinguir de personas -pero ¿no hay que amar en general y no en particular?-, y además eran todavía demasiado mozas. En este asunto como en otros muchos, la vejez era un grado. Pues no es esto lo que se deduce del relato de los viejos y Susana (Dn 13).

Es bien conocido el rigor de san Juan de la Cruz en la purificación de los afectos. Ni las raspas tienen que quedar de ellos. Hay que tener "igualdad de amor e igualdad de olvido" acerca de todas las personas, sean parientes o no, "y aun en alguna manera más de parientes, por el temor de que la carne y la sangre no se avive con el amor natural que entre los deudos siempre vive, el cual conviene mortificar para la perfección espiritual. Tenlos todos como por extraños, y desta manera cumples mejor con ellos que poniendo la afición que debes a Dios en ellos. No ames a una persona más que a otra, que errarás, porque aquel es digno de más amor que Dios ama más, y no sabes tú a cuál ama Dios más. Pero olvidándolos tú igualmente a todos, según te conviene para el santo recogimiento, te librarás del yerro de más y menos en ellos. No pienses nada de ellos, no trates nada de ellos, ni bienes ni males, y huye de ellos cuanto buenamente pudieres, Y si esto no guardas no sabrás ser religioso, ni podrás llegar al santo recogimiento ni librarte de las imperfecciones"146 (los subrayados son míos). No

145. $I b ., i b ., 13, i b ., 786$. Fray Luis de León elogió "la pureza y facilidad del estilo" de la Madre, "la gracia y buena compostura de las palabras y una elegancia desafeitada" (Epistolario, edición de José Barrientos García, Editorial Revista Agustiniana, Madrid 2001, Carta 77, 234. Carta a las carmelitas de Madrid.). Muchos, apoyados en su autoridad, se han deslizado por esa pendiente. Hace falta estar ciego de devoción por la santa, y fray Luis lo estaba, para no oírle el jadeo cuando escribe, ni ver los trompicones con que avanza. Santa Teresa no escribe, habla, habla con sus monjas. De ahí la frescura y espontaneidad de sus escritos, pero también las incorreciones lingüisticas, las digresiones y las incongruencias de todo tipo. No está el éxito de santa Teresa en su estilo, sino en la "torpeza" con que ensaya hacer hablar a su espíritu sin llegar a conseguirlo, pero permitiéndonos captar perfectamente cuál es la meta a que tiende, por qué es inaccesible, quién la persigue. Esta es su grandeza imperecedera (Cf. Francisco Rico, Breve biblioteca de atores españoles, Editorial Seix Barral, Barcelona 1990, 134-135).

146. Cautelas, $\mathrm{n}^{\circ}$. 5-6, en Vida y obras de san Juan de la Cruz, BAC, Madrid 197810, 423 424. 
valen aquí componendas, aquí no hay parvedad de materia. "Porque eso [lo mismo] me da que una ave esté asida a un hilo delgado que a un grueso, porque, aunque sea delgado, tan asida se estará a él como al grueso en tanto que no le quebrare para volar. Verdad es que el delgado es más fácil de quebrar; pero, por fácil que es, si no le quiebra, no volará. Y así es el alma que tiene asimiento en alguna cosa, que, aunque más virtud tenga, no llegará a la libertad de la divina unión"147. Pero "el santico de fray Juan"148, así le llamaba santa Teresa por lo chico que era ${ }^{149}$, no tenía "igualdad de amor e igualdad de olvido" con todos, ni tenía a todos "por extraños". Como santa Teresa, "por muchas causas" y "porque entendía con quién trataba" y "por sus años", tuvo también sus predilecciones, sus desaguaderos.

Así justifica sus predilecciones un investigador del santo: "El corazón entrañable del santo no podía por menos de tener sus predilecciones. Y las tenía. Las nadas exigidas por él en la Subida del Monte Carmelo como una condición necesaria para llegar a la divina unión [...]; doctrina que, mal entendida, ha creado en torno a su figura una leyenda negra de insensibilidad y tortura, no son en la mente del santo una finalidad, sino un medio, utilizable en los primeros momentos de la vida espiritual para evitar el peligro del afecto desordenado en el corazón aún imperfecto. Pero, una vez realizada la purificación, desaparece la necesidad de esa actitud, porque el corazón, limpio ya y ordenado, sacará bien de todo eso. Entonces no sólo puede, sino que tiene que amarlo, surgiendo las predilecciones que imponen la diferencia de las personas y la naturaleza del corazón, que en los santos es más auténticamente humano y sensible que en los demás, por lo mismo que han desaparecido por la purificación las desfiguraciones pasionales, recuperadas y robustecidas sus energías afectivas" 150 .

Uno, en su ingenuidad, creía que la renuncia a las criaturas era para toda la vida; que había que amarlas, sí, pero en Dios, por Dios y para Dios; sólo en él, por él y para él, raído del alma cualquier otro afecto; que las nadas exigidas por el santo ${ }^{151}$ lo eran de por vida "para llegar a serlo todo", es decir, para llegar a la unión con Dios, para "serlo todo en él", en quien están todas las cosas formal y eminentemente, como decían los escolásticos

147. Subida del monte Carmelo $1,10,4$, ib., 479.

148. Santa Teresa de Jesús, Cartas, 226, 8, ib., 908.

149. Cf. ÍD., íb., 246, 2, ib., 931; íb., 13, 2, íb., 681.

150. Fray CRISÓgONO DE Jesús, Vida de san Juan de la Cruz, en Vida y obras de san Jua de la Cruz, ib., 338-339. ¿Practicó el P. Crisógono su interpretación de la doctrina del santo?

151. Cf. San JuAn De la Cruz, ib., 1, 13, 5-12, ib., 483-484. 
y recuerda el santo. Su Amado es para él las montañas y los valles y las "ínsulas extrañas" y "el silbo de los aires amorosos", y en él goza todas las delicias que hay en las criaturas sin la penas y molestias que hay en ellas ${ }^{152}$. Pero no. Según estos entendidos, la renuncia a las criaturas sólo se da en la primera etapa del camino espiritual, en la vía purgativa o de purificación. Una vez que se han ordenado los afectos, ya puede uno tener sus predilecciones y sus cariños. ¿Se puede recuperar lo que se ha negado con las exigencias tan radicales que pone el santo? Y pasada la vía purgativa, ¿es ya el hombre sólo espíritu, de modo que ya nada puede en él la carne?¿No somos mientras estamos en esta vida carne espiritual o espíritu carnal, indisolublemente? Concedido que el amor sea entonces puramente espiritual, que no lo es, ¿no es precisamente este amor el que ama a todos por igual, sin distinción de personas? En consecuencia, si se admite la doctrina de las negaciones, ¿no habrá que practicarla durante toda la vida por muy dura que hoy nos resulte? En ninguna parte de sus obras la restringe el santo a los principios de la vida espiritual.

Pero ¿no habrá que olvidarse de esta antigua y venerable doctrina, tan venerable y antigua como los Padres del Yermo; que tiene menos de evangélica que de neoplatónica y maniquea? Ya santo Tomás de Aquino nos advirtió que no sólo Dios es el único objeto del amor en el orden de la caridad, sino que también lo son los hombres (y las mujeres, claro),y que la caridad no es la única razón para amarlos; también lo son los lazos de parentesco, los lazos de carne y sangre, la amistad..., y no hay nada malo en ello ${ }^{153}$.

La regla 32 de los jesuitas, "que todavía debe andar por ahí discretamente anestesiada, pero que en boca de mis maestros era norma rígida de conducta y criterio constatable de permanencia en la vocación, decía textualmente: Ninguno tocará a otro, ni aun por juego, si no fuese abrazando en señal de caridad al que va o vuelve de camino. Yo observé la prohibición con fidelidad convencida. Ayuno táctil en cadena perpetua. ¡Tristes heroicidades hemos hecho todos en nombre de la virtud...!"154. Conocía bien esta doctrina Gabriel Miró. Estas son las reflexiones que le hace decir en una de

152. Cf. Cántico espiritual $A$, Canciones 13-14 (B, 14 y 15), ib., 774-784 (B 896-907).

153. Cf. S. Th. I-II ae, qu. 26-28; II-II ae qu. 23-26; James McEvoy, Amitie, attirance et amour chez s. Thomas d'Aquin, en Revue Philosophique de Louvain 91 (1993) 383-408; Juan Martín VELASCO, Experiencia mística y experiencia del hombre en el mundo, en Iglesia Viva 161 (1992) 451-458. 137.

154. Carlos G. VAlLÉs, Mis amigos, los sentidos, Editorial Sal Terrae, Santander 1996, 
sus novelas al hermano portero de un colegio de jesuitas de alumnos seglares: "Cada vez que repicaba el esquilón de la portería, el hermano botaba de pesadumbre. ¡No podían vivir sin quererse, sin besarse, sin tocarse! ¡Oh qué engaños y peligros tenían los alumnos en sus familias; y singularmente en la madre, en la madre y en las hermanas"155. Una madre va a visitar a su hijo la tarde del Viernes Santo. Madre e hijo se besan. "Y el hermano portero los separó diciendo: ¡en esta tarde, Nuestra Señora no pudo besar a su Hijo sino después de muerto"156. Se podría hacer una antología alucinante de disparates sobre el particular, pero ¿a qué seguir? Allá cada uno con sus fantasmas.

\subsection{Gozos del tacto}

Somos cuerpo, cuerpo que siente y piensa -inteligencias sentientes- y se alegra y se acongoja; cuerpo táctil, que oprime y es oprimido; que acaricia y es acariciado. Para ser necesitamos relacionarnos con lo otro que nosotros, en especial con los otros. No despreciemos el tacto, no lo embotemos por desuso. Eduquémoslo. Este es, sin duda, el sentido más difícil de educar y el que mejor revela el dominio que uno tiene de sí mismo, porque en él la afectividad se hace cuerpo y el cuerpo se hace afectividad. Eduquémoslo en un proceso de madurez nunca acabado, sin miedo a la piel. "Qué embriaguez, tocar, tocar...; mi mano / febrilmente las cosas acaricia"157. "Hombre, toca, toca / lo que te provoca: / seno, pluma, roca, / pues mañana es cierto / que estarás ya muerto, / tieso, hinchado, yerto. / Toca, toca, toca, / ¿Qué alegría loca! /Toca. Toca. Toca"158. "Perdón por ir de prisa, / neciamente de prisa, / derrochando la vida, / perdiendo mis diez dedos y sus yemas / y sus tersos caminos"159. Hambre de piel hay en el hombre, y esto no se debe a un supuesto pecado original, aunque así lo digan los espirituales, que en esta materia, como en tantas otras, desbarraron sin medida. El hombre está hecho así. "Nuestra gran creación perceptiva es la caricia, que ennoblece la sensación con el sentimiento" 160 .

155. El obispo leproso, c. IV, en Obras escogidas, Aguilar, Madrid 19674, 908.

156. ÍD., ib., ib., 910.

157. Dámaso Alonso, Embriaguez, en Hombre y Dios, ib., 384.

158. Id., Gozo del tacto, ib., ib., 397.

159. Elisa de PAUT, Raíz y vuelo, cit. por Carlos G. VAllés, ib., 160.

160. José Antonio MARINA, El comienzo de todo, en ABC Cultural 28-2-97, 36. 


\section{EL OLFATO}

El olfato fue quizá el sentido más importante en las formas de vida primitiva. La jerarquía de los sentidos y la forma de valorarlos han cambiado en el decurso de la historia. En el comienzo de la humanidad, en una tierra casi despoblada de hombres, pero sobrehabitada de animales hostiles y poderosos, el olfato tuvo que ser el sentido de la supervivencia. Un olfato casi animal todavía, imprescindible para detectar la presencia de animales enemigos y encontrar comida. Aún hoy, los pueblos menos civilizados, aventajan por su olfato a los civilizados. En la actualidad, es el sentido menos explorado y el de vocabulario más pobre.

Aspiremos los aromas del campo. "Aroma de un campo que bendijo el Señor es el aroma de mi hijo" (Gn 27, 27). "El aire el huerto orea, / y ofrece mil olores al sentido; / los árboles menea / con un manso ruïdo, / que del oro y del cetro pone olvido"161. Aire de huerto en primavera, encabezado de aromas, y aire del Espíritu, que orea los dentros. "Me embriago de aromas. Qué delicia, / campo recién llovido castellano"162. Recordemos los perfumes que corren por el Cantar de los cantares, en sentido propio o como símbolo del amor, penetremos en su jardín cerrado, reposemos a la sombra de sus árboles -enebros, cipreses, manzanos....-, sobre el tapiz de sus flores -narcisos, azucenas, nardos..._-163. Recordemos también aquella "libra de ungüento de nardo legítimo, de gran valor", con la que María "ungió los pies de Jesús y los enjugó con sus cabellos, y la casa se llenó del olor del ungüento" (Jn 12,3), del perfume del amor y el cariño que una mujer le tenía. Recordemos el gran acierto de Süsskind al componer toda una novela, El perfume, sobre el prodigioso olfato de su protagonista ${ }^{164}$.

\section{EL GUSTO}

\subsection{El gusto en la infancia y en los pueblos primitivos}

El gusto es, biográficamente, el sentido que primero aparece en el recién nacido. El niño comienza a clasificar la realidad en dos series: la que

161. Fray Luis de León, Poesías completas, I, vv. 56-60, edición de Cristóbal Cuevas, Editorial Castalia, Madrid 2000, 91.

162. Dámaso Alonso, Embriaguez, ib., ib., 384.

163. Cf. Cantar de los cantares, traducción y comentario de Luis Alonso SCHÖKEL, Editorial Verbo Divino, Estella 1990, 55-57.

164. El perfume, Seix Barral, Barcelona $1998^{6}$. 
se puede chupar y la que no (porque quema, hiere, sabe mal, está fría, lejos, es áspera, demasiado grande...). "La primera interpretación humana es la que establece el niño al chupar las cosas -es, aunque pueda repugnar a una mente racionalista, la forma embrionaria de la razón-" 165.

$\mathrm{El}$ gusto fue decisivo en los pueblos primitivos, y sigue siéndolo en las formas de vida que llamamos, con impropiedad manifiesta, primitivas. Una palabra de tan nobles resonancias en la historia como sabio tuvo unos orígenes humildísimos. Etimológicaménte, sabio es "el que entiende de sabores", "el probador de alimentos", el que sabe a qué saben los alimentos buenos y a qué los malos, el que los distingue, una autoridad en materia tan importante.

En los pueblos civilizados, en cambio, el niño recibe de los padres y de la sociedad un sistema complejo de interpretaciones, ahorrándole el tener que hacérselas él. ¿Ventaja o desventaja? ¿Quién lo sabe? Lo cierto es que el olfato y el gusto, en nuestra cultura, apenas intervienen en la constitución de nuestro mundo vital. Su papel es secundario, marginal, al lado del que desempeñan los otros tres sentidos. Olfato y gusto han andado siempre juntos. Lo dice el refrán: "mal oledor, mal catador".

\subsection{El placer de comer}

Hay que comer para vivir, no vivir para comer, dice un refrán. No es verdad. En los albores de la humanidad, se comía, en efecto, para vivir, como lo hacen los animales. Pero desde que se inventó la cocina y el aliño de los alimentos, el placer, más que la necesidad, nos lleva a la mesa. Si comiéramos sólo por necesidad, estaría de más la preparación de los alimentos, y habría que reducir considerablemente la cantidad, al menos en los países desarrollados. La evolución que sigue la satisfacción del hambre en el individuo se corresponde, como en otros procesos, con la que ha seguido en la especie. Como suele decirse, la ontogénesis repite la filogénesis. El niño come para vivir. Ni le importa lo que come ni sabe para qué. Cuando empieza a tener conciencia e iniciativa, a la mera necesidad de comer se sobrepone el placer, que se mantiene hasta la ancianidad, en que vuelve a prevalecer la necesidad. El refrán citado "expresa el punto de vista del anciano, que es siempre el que inventa y acredita los proverbios. Se come para vivir, en efecto, pero en la ancianidad. En la juventud se vive para gozar de todo, pero por el goce y no 
por la necesidad. Cada edad tiene su moral, y los refranes morales, inventados por los viejos, se olvidan generalmente de la juventud" 166 .

\subsection{Las comidas de Jesús}

Hablando del gusto, hay varios pasajes evangélicos que no podemos olvidar, porque en ellos se nos revela la actitud de Jesús en este asunto de los sentidos. Una actitud muy alejada de la de los ascetas de otros tiempos, que se ahilaban con ayunos, mezclaban ajenjo en su parva comida, e incluso lloraban por tener que "echar pienso al asnillo del cuerpo", que así decían. La imitación de Jesucristo aquí no ha funcionado. "Vino Juan, que ni comía ni bebía, y dijeron que tenía un demonio dentro. Vino el Hijo del hombre, que come y bebe, y dicen: Vaya un comilón y un borracho, amigo de recaudadores y descreídos. Pero la sabiduría de Dios ha quedado justificada por sus obras" (Mt 11,18-19). Jesús y sus discípulos no ayunaban y por eso los acusaron los discípulos de Juan (Mt 9, 14-17). En respuesta, Jesús compara sus comidas con los discípulos a un banquete de bodas, en los que él es el novio, es decir, el esposo de una nueva alianza. Son para él el anticipo de la alegría y la amistad del banquete del Reino. Se acabaron "las judaicas ceremonias" como las llamaba Erasmo. No tienen sentido religioso. Jesús comía con publicanos y descreídos, con pobres y con ricos, con excluídos y con gentes del sistema ( Lc 7, 36-50; 19, 1-10; Jn 12, 1-7). Y nos dejó como memorial suyo un banquete, la Eucaristía, aunque hoy se le parezca poco. Donde está Jesús, hay alegría y amistad liberadora. Lo antiguo pasó. Ha llegado lo nuevo (2 Cor 5,17$)$. Novedad absoluta sin resabios de odres viejos. Sí a la vida, al gozo de los sentidos. Pero, ¡ay!, las "judaicas ceremomias" retornaron pronto, y con qué fuerza. ¿Seremos capaces de conjurarlas para siempre?166 bis.

\section{LA ESTRUCTURA SENSORIAL DE LA REALIDAD}

En la actualidad, en Occidente, vista, oído y tacto estructuran sensorialmente el mundo de los adultos en sus tres dimensiones radicales: mundanidad, significación y realidad. Pero no siempre fue así. En la visión y en

166. Gregorio MARAÑón, Reflexiones sobre el hombre y la alimentación, en Obras completas, Espasa-Calpe, Madrid 1957, III, 195. 166 bis. Cf. Rafael AGUIRRE, La mesa compartida. Estudios del Nuevo Testamento desde las ciencias sociales, Sal Terrae, Santander 1994.

166bis. Cf. Rafael Aguirre, La mesa compartida. Estudios del Nuevo Testamento desde las ciencias sociales, Sal Terrae, Santander 1994. 
la audición, sentimos las cosas fuera de nosotros; en el gusto y en el olfato, las sentimos en ciertas porciones de nuestra superficie corporal; pero en el tacto, las sentimos dentro de nuestro cuerpo. El tacto es, en realidad, contacto entre el cuerpo que tocamos y nuestro cuerpo con el que lo tocamos; entre algo que resiste y nuestro cuerpo que es resistido; entre el objeto que nos oprime y nuestro músculo oprimido. Las cosas chocan con nuestro cuerpo, y, por eso, nos son cuerpos. Si no pudieran chocar con nosotros, es decir, si nosotros fuéramos espíritus puros, las cosas no serían cuerpos para nosotros, no podríamos sentirlas, tocarlas, manejarlas, trasladarlas, modificarlas, destruirlas, en suma, influir en ellas.

Ver, oír, tocar, gustar y oler no son operaciones meramente pasivas. Con el sentir pasivo, inseparable de él, hay un sentir activo. Sucede todo con tanta facilidad, que nos parece que nosotros no intervenimos en absoluto en nuestras sensaciones, pero intervenimos. Por eso, en realidad no hay sensaciones, que ellas solas serían un caos, sino percepciones, sensaciones interpretadas. Y por eso, lo que está en nuestro derredor, la circunstancia, es siempre mundo, circunstancia interpretada. En el tacto, que es un sentido lento, lo podemos comprobar. En él podemos asistir a nuestra propia percepción, experimentar nuestra participación en la sensación táctil. Intentemos reconocer un objeto mediante el tacto. Lo exploramos, tratamos de identificarlo con algo conocido. Con los datos adquiridos, formulamos hipótesis, que comprobamos mediante nuevos contactos, que las confirman o las rechazan. Si confirman alguna, aparece el significado. La más simple de las percepciones es una operación complejísima. Reconocer por el tacto una cosa vista, o viceversa, es tan complejo que pocos animales, incluidos los simios, pueden hacerlo. Un niño pequeño lo hace ${ }^{167}$.

No hay, por consiguiente, un mundo interior y otro exterior, un mundo sensible y otro inteligible. Hay un mundo, uno solo, el mío, el tuyo, el de cada uno, que es, a la vez, exterior e interior, sensible e inteligible. Ver es interpretar, y lo es oír y tocar y oler y gustar. Sentir es percibir, entender. Pensamos viendo, y oliendo y tocando y oyendo y gustando, y vemos y olemos y tocamos y oímos y gustamos pensando. Lo demás son musarañas, nada que ver con el hombre. Hay que superar el pensamiento heredado de los griegos, sobre todo el de tradición neoplatónica y el de la tradición gnóstica

167. Cf. José Antonio MARINA, Teoría de la inteligencia creadora, edic, cit., 35. Para una consideración actual de los llamados "sentidos espirituales" a partir de la fenomenología de los sentidos corporales, cf. Hans URS VON BALTHASAR, Ver, oír y leer en el ámbito de la Iglesia, en Ensayos teológicos, Ediciones Guadarrama, Madrid 1964, II, 561-581; ÍD., Contemplar, creer, comer, en ib., ib., 583-595. 
y maniquea. Hay que superar la espiritualidad monástica y frailuna, sacudirnos sus cadenas, y hablar por cuenta propia, desde nuestro nivel histórico.

\section{EL GOZO DE LOS SENTIDOS}

De ordinario, hablamos de cinco sentidos, pero los psicólogos cuentan hasta once. Sentidos que debemos procurar tener en buen uso, bien templados, para que su música suene perfecta. Azorín elogia en uno de sus personajes, don Pablo, contrafigura suya, "su gozar codicioso de las ideas, del contraste y relación de las ideas; su fruición lenta y suave del mundo, de las formas, del color, de las gradaciones de la luz, del silencio"168. "El mundo, dice un poemita japonés, un haikú, es una gota de rocío, pero ¡es tan bello!".

"¿Se puede compartir una vida profunda con otros, comprometerse con ellos sin tocarse jamás, sin que los sentidos se vean implicados, sin festejarlo de tiempo en tiempo, sin encontrarse compartiendo manteles? Soñamos con un cristianismo que vuelva a tomar en serio los pequeños detalles de la vida cotidiana como parábolas del Reino. Soñamos que, siguiendo a Jesús, los placeres de la mesa y el tener en cuenta nuestra corporeidad sean el lugar simbólico en el que arraiguen los hábitos de mesa de todo un pueblo para el que dar gracias ("celebrar la Eucaristía") nace naturalmente de la comensalidad. En nuestro sueño, el placer tiene derecho de ciudadanía en toda comunidad y grupo como invitado permanente; placer de estar juntos, placer de ser tomado en serio y también de poder reír juntos, placer de comunicarse y de saber que Dios vio que todo esto era bueno" ${ }^{169}$ (Gen $1,10$. 12.18. 21. 25. 31).

La mala educación sensorial y sentimental que todos hemos recibido, todos, pero muy especialmente los educados en seminarios y conventos, ha creado en nosotros reflejos inhibidores, miedo a la comunicación, a las relaciones humanas, al poder de los deseos. La amistad se vio siempre como antesala de la homosexualidad, y se la anatematizaba como algo nefando. Caridad con todos, amistad con ninguno, se decía, ignorando que la amistad auténtica, la amistad fuertemente personalizada, es el mejor camino para relacionarse con todos sin traumas ni complejos. Los maestros espirituales del pasado, desde los Padres del Yermo hasta el Concilio Vaticano II, cie-

168. AzORÍn, Doña Inés, edic. cit., 205.

169. Sylviane.SALZMANN y Ambroise BINZ, Quand l'initiation nous dessine un a-venir, en Lumen Vitae 56 (2001) 70. 
gos para estos asuntos, no nos sirven. Nos separan de ellos años luz. Con razón se ha dicho que entre ellos y nosotros se abre una sima insalvable ${ }^{170}$. No reconocerlo es seguir recomendando lecturas y modelos inapropiados para nuestros tiempos, empeñarse en que la gente continúe viviendo en el ayer; pero la gente sigue su camino y, cada vez más, se desentiende de los encantadores de serpientes, es decir, de los clérigos.

Volvamos a los evangelios. Redescubramos a Dios, "que ama la vida" (Sab 11, 26); que "ama a todos los seres y no aborrece nada de lo que ha hecho; pues, si hubiera odiado alguna cosa, no la habría creado" (Sab 11, 24). Redescubramos a Jesús, que ha venido "para que tengan vida y la vida les rebose" (Jn 10, 10). El Evangelio tiene todavía mucho que decir en la hora actual. Dios no "se hizo hombre y habitó entre nosotros" (Jn 1,14) para que nosotros nos hagamos dioses renunciando a ser hombres, como se ha dicho, sino para que seamos dioses haciéndonos hombres, plenamente hombres; "para que todo el que crea en él tenga vida definitiva y ninguno perezca" (Jn 3, 16).

A los místicos, y en general a los espirituales, hay que hacerles fundamentalmente tres reparos ${ }^{171}: 1^{\circ}$. Según ellos, la cima de la vida espiritual en este mundo es la unión con Dios, con el Uno, el retorno del alma a la Unidad original. Una desmesura que plantea serios problemas a la modestia y a la obscuridad insuperable de la fe, ya que "ahora vemos confusamente en un espejo" (1Cor 13, 12). "A Dios nadie lo ha visto jamás; es el Hijo único, que es Dios y está al lado del Padre, quien lo ha explicado" (Jn $1,18)$. "A Dios nadie lo ha visto nunca" $(1 \mathrm{Jn} 4,11)$. Los problemas se agravan cuando nos describen esta unión, y descubrimos que trabajan sobre la falsilla de la unión sexual, tal como se celebra en el Cantar de los cantares. Léase, por ejemplo, esa maravilla que es el poema En una noche oscura, de san Juan de la Cruz. Lo que en él se describe, según nos dice él en los comentarios, es la unión amorosa con Dios; pero el hecho es que no la describe directamente, sino dando un rodeo por la unión sexual, o sea, un coito a lo divino. Se apunta a aquella, según él, pero se nos dice esta. Unión casi física, pues el placer espiritual que se experimenta desborda sobre el cuerpo, que goza también a su manera ${ }^{172}$. Obligado por sus superiores a comentar

170. Cf. Colette FRIED LANDER, Hors du monde? La vie monastique questionnée, en Vie Consacrée 68 (1996) 151-154.

171. Cf. Jean-Pierre JossuA, prólogo a M. Cornuz, Le ciel est en toi. Introduction à la mystique chrétienne, Labor et Fides, Genève 2001.

172. Cf. José VEGA, Eucaristía y convivencia según la Escuela Agustiniana Española del siglo XVI, en Estudio Agustiniano 33 (1998) 75-89. 
sus poesías, el santo se va con frecuencia por los cerros de Úbeda. Ya solo habla de la realidad aludida, nunca de la que le sirve de comparación. Con el pretexto de comentar sus poemas, lo que hace es escribir unos tratados de teología mística que nada tienen que ver con ellos. Es como si "a García Lorca o a Vicente Aleixandre se les hubiera pedido o mandado por santa obediencia verter en prosa el "significado" de Poeta en Nueva York o de La destrucción o el amor"173, y los comentaran espiritualmente. Resultarían, inevitablemente, dos mundos distintos, dispares, sin posible comparación entre ellos. Algunos de los episodios de la vida de los místicos, algunos de sus éxtasis, visiones, transverberaciones, matrimonios espirituales, besos divinos y embarazos místicos, toques en el corazón, ser amamantado por la Virgen como san Bernardo, dar de mamar al niño Jesús -lactatio Christidan mucho que pensar. Margarite Ebner, monja alemana dominica, se apretaba un niño Jesús contra sus pechos desnudos para darle de mamar, y en el sueño Cristo yacía desnudo junto a ella. A Matilde de Magdeburgo Cristo la mandó desnudarse diciéndole: "Os haré parte de mi naturaleza". Santa Ángela de Foligno se desnudó, toda estremecida, delante de un Cristo diciéndole. "Haced de mí lo que queráis". De sor Juana de la Cruz es mejor no hablar. El alma de los místicos es mujer y Cristo es su amado. Hasta tal punto que Enrique de Suso vestía de mujer ${ }^{174}$. El "vuelo" místico resulta a la postre un fracaso, y, contra su voluntad, en él se transparenta lo humano, lo demasiado humano, de lo que ellos dicen huir. Es verdad que santa Teresa de Jesús dice que la verdadera unión con Dios es el amor al prójimo, porque no podemos saber si amamos a Dios, pero sí si amamos al prójimo ${ }^{175}$. Aquí ya nos entendemos. $2^{\circ}$. La insistencia en la huida del mundo y su desprecio, en el despojo radical de todo lo humano, en el vaciamiento de toda criatura, en la desnudez y negación de lo sensible, del mundo, de los otros, del cuerpo, del pensamiento, de uno mismo, porque todo está lastrado de impureza, es incompatible con la creación de todo por Dios y la encarnación de su Hijo, dos afirmaciones fundamentales del cristianismo. Este doble postulado, la unión con el Uno y el vaciamiento radical para conseguirla, extraño a la Biblia, proviene del platonismo y, sobre todo, del neo-

173. Ángel AlCALÁ, Poetas del amor y del silencio. A propósito de fray Luis de León y de san Juan de la Cruz, en Monte Carmelo 102 (1994) 46.

174. Sobre erotismo y mística, cf. Fernando R. de la FLOR, La península metafísica, Biblioteca Nueva, Madrid 1999, 233-266; Odon VALLET, Le honteux et le sacré. Grammaire de l'erotisme divine, Albin Michel, Paris 1998; Philippe CAMBAY, L'erotisme et le sacré, Albin Michel, Paris 1989.

175. Moradas del castillo interior, 5, 3, en Obras completas, BAC 1979. 398-401. 
platonismo, que tuvo su expresión máxima en Plotino. ¡Cuidado con los neoplatónicos cristianos! $3^{\circ}$. Es evidente que a partir de los Carolingios se perdió la dimensión eclesial y comunitaria de la fe, degenerando en un individualismo religioso, incluso en la celebración de la misa, que comenzó a celebrarse sin la asistencia de fieles, como cosa exclusiva de los sacerdotes, los hombres de lo sagrado ${ }^{176}$. Lo que hace que hoy, en este aspecto, nos sintamos más cerca de los Padres de la Iglesia que de los que vinieron después como ya señaló Congari77.

No hay que tapiar los sentidos, anularlos, como enseñaban los espirituales, sino vivirlos gozosamente. "¡Salir por fin, salir / a glorias, a rocíos [...]. / Resbalar sobre el fresco / dorado del estío. [...] / Lanzar, lanzar sin miedo / los lujos y los gritos / a través de la aurora / central del paraíso. / Ahogarse en plenitud / y renacer clarísimo!"178. Hay que apreciar lo que nos rodea, gozarlo y sufrirlo; continuar la creación, que no está acabada (Jn 5, 17), amándola activamente. "Y yo había dicho. ¡Vive! / Es decir: ama y besa, / escucha, mira, toca, / embriágate y sueña"179.

A Dios no se le encuentra dentro, en la torre de marfil del "sí mismo" - ¿qué podría hacer ahí?-, sino fuera. Para encontrarle hay que salir del "si mismo", trascenderlo; pero no hacia arriba, "por la Luna y más allá" al estilo de los neoplatónicos, como tantas veces se ha dicho, sino hacia acá abajo, haciéndose prójimo del necesitado (Lc 10, 29-37), dando de comer al hambriento y de beber al sediento... (Mt 25, 31-46), haciendo el bien (Hech 10, 38). A Dios se le encuentra en la vida, en la interacción del proyecto vital y la circunstancia, o sea, en un fuera que es un dentro y en un dentro que es un fuera. Dios habla ahí fuera, en los otros, en el rostro de los otros, en especial en el rostro sufriente de los marginados, aunque para escucharle haya que recogerse en silencio. Lo cual no tiene nada de extraño, porque hasta para entender la más elemental de las verdades, que dos y sos son cuatro, por ejemplo, necesitamos recogernos y pensarla en silencio como repite Ortega y Gasset.

176. Cf. André Vauchez, La espiritualidad del Occidente medieval (siglos VIII-XII), Ediciones Cátedra, Madrid 1985, 17-20.

177. Cf. José Jiménez LOZANo, Un prestigio para el pensamiento católico, en La ronquera de fray Luis y otras inquisiciones, Ediciones Destino, Barcelona 1973 247-251; José VEGA, Eucaristía y convivencia según la Escuela Agustiniana Española del siglo XVI, en Estudio Agustiniano 33 (1998) 72-74.

178. Jorge GulLÉn, Nivel del mar, en Aire nuestro. I. Cántico, Barral Editores, Barcelona 1977, 490. 109.

179. Manuel Machado, "Ars moriendi", en Antología, Espasa-Calpe, Madrid 19596, 
La vida, la vida humana experimentada y vivida, es la verdad. Ella, no la Ley, es la que debe guiar a los hombres. El anhelo de vida, de ser, de ser más, de ser en plenitud, está ínsito en la realidad humana. Por ahí hay que encaminar los pasos. "Y la vida era la luz de los hombres" $(\mathrm{Jn} 1,4)^{180}$. No hay que negar la vida, sino amarla y gozarla. A Dios, que "es vida" (Jn 6, 57; 14, 6; 1Jn $1,1-4)$, no se va por la negación de las criaturas, menos por la de uno mismo, por las "nadas" sanjuanistas ${ }^{181}$, sino por la vida y el amor, como fue el que es "camino, verdad y vida" (Jn 13,6). Estamos en Dios, religados a Él, "no precisamente para huir del mundo, de los demás y de sí mismo, sino al revés, para poder aguantar y sostenerse en el ser. Es que Dios no se manifiesta primariamente como negación sino como fundamentación, como lo que hace posible existir. [...] El hombre no encuentra a Dios primariamente en la dialéctica de las necesidades y de las indigencias. El hombre encuentra a Dios precisamente en la plenitud de su ser y de su vida. Lo demás es tener un triste concepto de Dios. Es cierto -todos los hombres somos víctimas de inelegancias- que apelamos a Dios cuando truena. Sí, de esto no está exento nadie. Pero no es la forma primaria como el hombre va a Dios y "está" efectivamente en Dios. No va por la vía de la indigencia sino de la plenitud, de la plenitud de su ser, en la plenitud de su vida y de su muerte. El hombre no va a Dios en la experiencia individual, social y (sic) histórica de su indigencia; esto interviene secundariamente. Va a Dios y debe ir sobre todo en lo que es más plenario, en la plenitud misma de la vida, a saber: en hacerse persona. En el ser personal, en el ser relativamente absoluto de la persona, es donde encuentra a Dios"182. Por eso hoy se habla del evangelio de la vida.

\section{MUNDO EXTERIOR E INTERIOR}

No hay, por consiguiente, un mundo exterior y otro interior. Hay un mundo, sólo uno, que es, a la vez, exterior e interior, sensible e inteligible. Pero nos hemos formado en la dirección contraria a la aquí expuesta. No se tuvo en cuenta el aviso de san Pablo:"Una vez que habéis muerto con Cristo a los elementos del mundo, ¿por qué sujetaros, como si aún vivierais en el

180. Cf. Juan MATEOS- Juan BARRETo, El Evangelio de Juan, Ediciones Cristiandad, Madrid 1979, 56-58.

181. Cf. San JuAn de la Cruz, Subida del monte Carmelo, 1. 1, c. 13, en Vida y obras de san Juan de la Cruz, BAC, Madrid 1978, 482-484.

182. Xavier ZUBIRI, El hombre y Dios, Alianza Editorial / Sociedad de Estudios y Publicaciones, Madrid 19852, 344 . 
mundo, a preceptos como no tomes, no gustes, no toques, cosas todas destinadas a perecer con el uso y debidas a preceptos y doctrinas puramente humanos?" (Col 2, 20-22). Había que mortificar los sentidos, purificarlos, negarlos, matarlos. La realidad quedaba, inevitablemente, ignorada. Había que huir de lo exterior y refugiarse dentro de uno mismo. "Olvido de lo criado, / [...] atención a lo interior"183. Las consecuencias han sido fatales. Nuestro decir es abstracto. Nuestras homilías, fuera de contexto. Valen para todos los tiempos y lugares, o sea, para ninguno. Nuestros escritos, ilegibles. Nuestras conferencias, paseos por la historia universal, vacuidades Porque nuestro saber, cuando sabemos, es de libros, no de realidades, que sólo por los sentidos podemos aprehender. "Yo soy poco capaz para las generalizaciones. Mi modesta verdad se ha formado en la observación y la meditación de la cosas concretas, las que yo directamente he vivido, y sólo sobre ellas me considero capacitado para hablar. Pero no creo que esto sea un inconveniente por tres razones: primero, porque una pequeña verdad recogida en la vida es más útil que cien verdades recogidas en los libros [...]"184. De las homilías de San Manuel Bueno, mártir, dice su narradora Ángela Carballino: "¿Qué cosas nos decía! Eran cosas, no palabras"185.

¡Cuidado con la interioridad! En el interior no hay verdad alguna. Tampoco en el exterior. La verdad se hace, y se hace en conexión con el exterior, en interacción permanente entre el mundo y la conciencia. Para crecer como personas necesitamos absorber el entorno, un entorno rico, variado y estimulante. La interioridad se hace con la exterioridad y esta existe porque existe aquella. No hay más que un mundo, exterior e interior. Interioridad y exterioridad no se excluyen, sino que se necesitan y se complementan mutuamente. La interioridad hay que hacerla con realidades, no con espectros; se hace, sobre todo, con personas, con ellas y para ellas.

$$
\begin{array}{r}
\text { José VEGA } \\
\text { Estudio Teológico Agustiniano } \\
\text { Valladolid }
\end{array}
$$

183. San JUAn De la CRuZ, Poesías, en Vida obras de san Jan de la Cruz, edic. cit, 409. "Olvido de lo criado" ¿De veras? ¿Habría escrito él lo que escribió si se hubiera olvidado de lo creado? Su poesía, cima de belleza, no vino de dentro, sino de fuera, de sus lecturas y del gozo de los sentidos. Nada aparece por generación espontánea. En toda obra literaria, los elementos informativos y culturales procedentes del exterior son decisivos. Mucho más que el substrato de neuronas que los recibe. No hay inspiración sino transpiración, trabajo, esfuerzo.

184. Gregorio MARAÑón, La vocación, en Obras completas, Espasa-Calpe, Madrid 1967, III, 987. 62

185. Miguel de Unamuno, San Manuel Bueno, mártir, Editorial Castalia, Madrid 1984, 